\title{
IDENTIDADES SOCIALES Y MODOS DE EDUCACIÓN. ENTREVISTA A JULIA VARELA FERNÁNDEZ ${ }^{\alpha}$
}

\author{
Social identities and modes of education. \\ Interview to Julia Varela Fernández.
}

\section{Ana Iglesias Galdo ${ }^{\beta}$}

Resumen. Tras esbozar algunos apuntes autobiográficos que permiten rastrear los orígenes de su interés por la educación escolar, y también de su conciencia social sobre las injusticias enraizadas en nuestras instituciones sociales, la profesora Julia Varela hace un recorrido por los inicios de su formación como socióloga, en el contexto de mayo del 68 en París y en la Universidad de Vincennes, y explica las razones que la llevaron a decidirse por la sociología histórica, por la genealogía, como método de conocimiento.

A continuación, acogiéndose a la temática del presente monográfico, profundiza sobre la historia del sistema escolar y el peso que los modos de educación tienen no solo en la formación de las subjetividades individuales, sino también en las identidades sociales, haciendo un recorrido por tres de sus obras: Modos de educación en la España de la Contrarreforma (1983), Arqueología de la escuela (1991) y Nacimiento de la mujer burguesa (1997, 2019). Explicita también brevemente la vinculación de estos estudios con otros libros suyos: A Ulfe (2004), Mujeres con voz propia (2011), Memorias para hacer camino (2016) y Mercedes Valcarce Avello. Maestra de maestros (2018). La entrevista finaliza con una breve reflexión sobre las razones que sustentan hoy la importancia de la educación pública como palanca para favorecer cambios sociales democráticos. Una transformación del sistema educativo al servicio de una mayor

\footnotetext{
a A sugerencia del profesor Narciso de Gabriel empecé a leer los trabajos de Julia Varela durante los cursos de doctorado, hace más de veinte años. Durante este tiempo ambos se fueron convirtiendo en referentes intelectuales imprescindibles. También fue Narciso quien propuso realizar esta entrevista, que Julia fue convirtiendo en un trabajo colectivo, en una interesante conversación, sosegada, de esas que a una le gustaría prolongar.

${ }^{\text {B }}$ Universidade da Coruña. Facultade de Ciencias da Educación. Departamento de Pedagoxía e Didáctica. Campus de Elviña, 15071 A Coruña, España. ana.iglesias@udc.es
} 
libertad y de una mayor igualdad, así como a favor del desarrollo cultural, contribuiría no solo al perfeccionamiento social, sino que convertiría además al sistema democrático de enseñanza en un sólido rompeolas capaz de ofrecer resistencia a la actual marejada del fundamentalismo neoliberal.

Palabras clave: Sociología de la educación; Genealogía; Relaciones de poder; Estratificación social; Modos de educación; Dispositivo de feminización; Socialización; Identidades sociales; Cambio social; Democracia; Neoliberalismo.

Abstract. After outlining some autobiographical notes that allow us to trace the origins of her interest in school education, and also of her social awareness about the injustices rooted in our social institutions, Professor Julia Varela takes a tour to the beginnings of her training as a sociologist, in the context of May 68 in Paris and at the University of Vincennes, and explains the reasons that led her to decide on historical sociology, on genealogy, as a method of knowledge.

Then, taking into account the theme of the present monograph, she deepens on the history of the school system and the weight that the modes of education have not only in the formation of individual subjectivities, but also in social identities, making a journey through three of her works: Modos de educación en la España de la Contrarreforma (1983), Arqueología de la escuela (1991) y Nacimiento de la mujer burguesa (1997, 2019). She also briefly explains the link between these studies and other of her books: A Ulfe (2004), Mujeres con voz propia (2011), Memorias para hacer camino (2016) y Mercedes Valcarce Avello. Maestra de maestros (2018). The interview ends with a brief reflection on the reasons that support the importance of public education today as a lever to favor democratic social changes. A transformation of the educational system at the service of greater freedom and greater equality, as well as in favor of cultural development, would contribute not only to social perfection, but also make the democratic education system a solid breakwater capable of offering resistance to the current swell of neoliberal fundamentalism.

Keywords: Sociology of education; Genealogy; Power relationships;Social stratification; Modes of education; Feminization device; Socialization; Social identities; Social change; Democracy; Neoliberalism.

Julia Varela es una socióloga de la educación que ha estudiado con rigor y autoridad, desde una perspectiva crítica, los orígenes y funciones de los modos de educación, así como el funcionamiento de «la maquinaria escolar». Son bien conocidos también sus trabajos de sociología del género. 


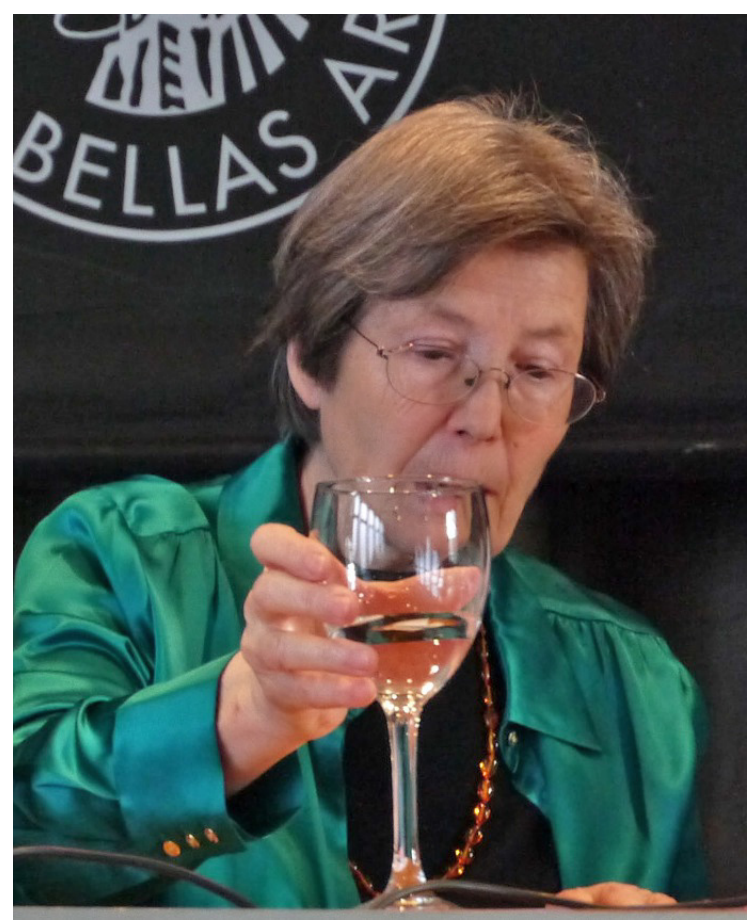

Julia Varela en el homenaje a Robert Castel, Círculo de Bellas Artes, Madrid 2013.

Doctora en Ciencias de la Educación por la Universidad Complutense de Madrid y Doctora en Sociología por la Universidad de París VIIIVincennes, es catedrática de Sociología en el Departamento de Sociología VI de la Facultad de Ciencias de la Información de la Universidad Complutense de Madrid —en la actualidad profesora honorífica-. Sus investigaciones, regidas por la pasión por el conocimiento, por la libertad de pensamiento, y por un fuerte compromiso en la búsqueda de la verdad, evidencian una voluntad de contribuir a la democratización de las instituciones educativas.

Su nombre está ligado a dos importantes proyectos editoriales. Por una parte dirigió, con su compañero, el profesor Fernando Álvarez-Uría, la colección "Genealogía del poder» de la editorial La Piqueta desde sus inicios en 1979 — se inauguró con el libro de Michel Foucault Microfísica del poder-. En las solapas de esta primera obra, escriben que esta colección está 
destinada a proporcionar materiales que puedan ser utilizados por todos los que habiendo renunciado a la vieja concepción globalizante de la política, luchan en espacios específicos contra poderes locales y capilares [...]. La genealogía es gris: es meticulosa y pacientemente documentalista [...]. Su finalidad es hostigar y subvertir el poder allí donde éste se ejerce.

La colección Genealogía del poder fue sin duda una de las principales plataformas que propiciaron la introducción de la obra de Michel Foucault en España, así como de Karl Polanyi, Norbert Elias, Robert Castel y otros, al servicio de nuevos análisis críticos. Este imprescindible trabajo «artesanal» de ediciones y traducciones, a contracorriente, que se plasmó en 38 libros, jugó y juega un papel fundamental en la adquisición de nuevos modos de indagación de la historia de los sistemas de pensamiento, contando con una gran acogida en movimientos sociales que buscan alternativas al orden instituido para avanzar con rapidez en el proceso de democratización. Por otra parte colaboró también muy activamente en el Consejo de redacción de la revista Archipiélago: cuadernos de crítica de la cultura, que nació como una cooperativa de crítica cultural (1988-2008) y publicó 84 números monográficos.

Julia Varela recibió el Premio Vicente Risco de ciencias sociales por su obra A Ulfe. Socioloxía dunha comunidade rural galega, un libro sobre el mundo rural en el que no solo se pone de manifiesto la complejidad de las relaciones sociales en una pequeña aldea gallega, sino también los retos que plantean a nuestras sociedades la desaparición del campesinado y el abandono del mundo rural.

Más que abordar en este breve espacio su amplia, intensa e interesante producción científica, nos vamos a limitar a citar algunos de sus libros y a seleccionar algunas de sus publicaciones en revistas y obras colectivas que están especialmente relacionadas con las temáticas abordadas en esta entrevista. Entre las diversas revistas con las que ha colaborado podemos citar a la ya mencionada Archipiélago, Abaco: Revista de cultura y ciencias sociales, Revista de Educación, Con-ciencia social, Educación y Sociedad, Papers: Revista de sociología, Claves de razón práctica, Sarmiento: Revista galego-portuguesa de Historia da Educación, Cuadernos de Pedagogía, Teknocultura... 
Julia Varela insiste en que el trabajo intelectual es un trabajo colectivo, e intercala en su discurso, como si de una conversación real se tratara, los referentes en que sustenta su particular manera de abordar una investigación. Insiste también mucho en que hay que volver a los clásicos.

Para empezar, agradecemos a Julia Varela esta entrevista, y aprovechamos para agradecerle también su trayectoria intelectual, pues tenemos la certeza de que contribuye a hacernos más libres.

\section{¿Cómo recuerdas tu infancia y tu experiencia escolar?}

Nací en un pueblecito del municipio de Chantada en la provincia de Lugo en donde había una casa-escuela y mi madre era la maestra. Se llamaba como yo, Julia, y se había casado con un hijo de un labrador de la zona que se llamaba José, mi padre. El pueblecito se llamaba Ulfe, parece que el nombre tiene origen germánico, «tierra de lobos». Estaba rodeado de sotos y montañas, pero ya bastantes de ellas habían sido roturadas para sembrar sobre todo centeno.

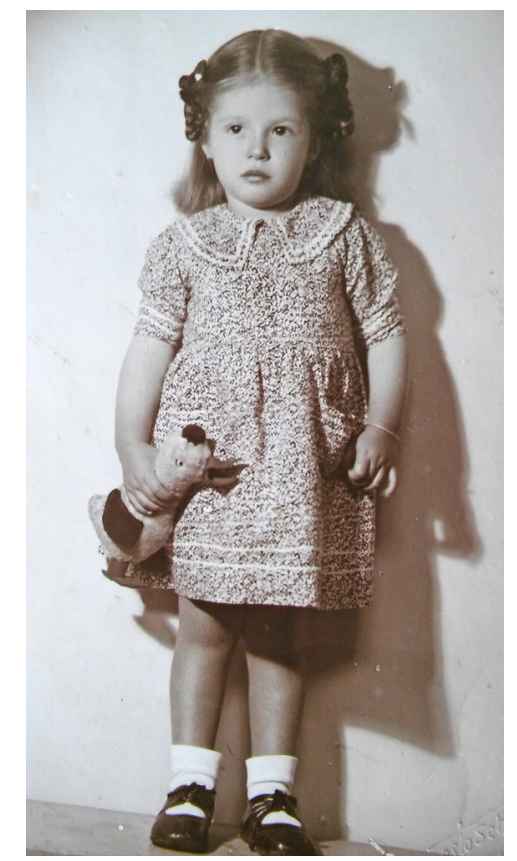

Julia Varela a la edad de 3 años, en Chantada. 
En ese pueblo, y en casa de mi abuelo paterno que estaba cerca, pasé mi infancia. Me dicen que me movía por el pueblecito desde que podía andar con mucha soltura, entraba en casa de todos los vecinos, y a veces me quedaba a desayunar o a comer ya que me gustaba más la comida que hacían que la de mi casa. Me trataban muy bien y me querían mucho, de ahí que algunos recuerdan que era «el chiche del pueblo». Pero como era bastante trasto, si me veían hacer algo que no debía hacer me llamaban la atención. Era una socialización en comunidad. Y aunque no todo era maravilloso en la infancia, tengo un grato recuerdo de mis cortos años. Y sin duda esa inmersión en la cultura campesina, con su vida cotidiana, sus ceremoniales, y fiestas, ha contribuido en buena medida a hacer de mí lo que soy. De ahí que ya de mayor, y cuando la civilización rural estaba a punto de desaparecer, haya escrito un libro, A Ulfe, para darles las gracias, y quizás con la ingenua intención de que ese rico y civilizado mundo perdure.

¿Cómo era la escuela donde ejercía tu madre, cuántos niños y niñas habia, qué materiales usabas, qué hacíais? ¿Era importante la disciplina, era un alumnado muy heterogéneo, era una enseñanza muy ideologizada, tenía mucho peso la religión?

La escuela en donde ejercía mi madre era lo que entonces se llamaba escuela mixta, a la que asistían niñas y niños de diferentes pueblecitos de la parroquia de distintas edades. Seríamos unos 60, y todos eran hijas e hijos de campesinos. Mi madre se había formado como maestra en la Escuela Normal de Lugo durante la Segunda República. Haciendo un juicio, a posteriori, pienso que era lo que se podía decir una buena maestra. Creo que sobre todo estaba interesada en que aprendiésemos bien a leer, escribir y hacer cuentas, lo básico, aunque también debíamos de tener alguna especie de enciclopedia, y había bastantes libros, en los que aprendíamos rudimentos de historia, geografía, ciencias... Había mapas colgados de las paredes... Y lo que para mí fue posteriormente más importante, no estaba muy preocupada por la disciplina. Recuerdo a los pequeños, que se sentaban cerca de su mesa, moviéndose por la clase, libremente hasta cierto punto. Y alguna vez a alguien de pie castigado ante el encerado, o sin poder ir al recreo. En la parroquia había un cura bastante culto, D. Teolindo, que posiblemente había sido enviado allí como castigo, así que nunca venía a la escuela. Era mi madre la que nos hacía aprender el catecismo de memoria y supongo que nos daría 
algunas nociones de religión cuando íbamos a hacer la primera comunión, que supongo tampoco entendíamos.

En consonancia con esa especial relación que tenían los campesinos gallegos con la religión no recuerdo mucha presión en este sentido. Mi padre se confesaba una vez al año, por Pascua Florida, y los hombres que iban a misa solían quedarse atrás en la iglesia los domingos y a veces entraban tarde a la iglesia pues quedaban en el atrio charlando y fumando un pitillo. La misa, los funerales, etc. eran sobre todo actos sociales en los que los familiares y los vecinos de distintos pueblos charlaban de sus asuntos, se ponían de acuerdo para hacer trabajos, y se pasaban información sobre las cuestiones que les afectaban. Eso sí, se quejaban de que $\mathrm{D}$. Teolindo sabía todo de la vida de sus parroquianos, supongo que sería sobre todo a través de la confesión de las mujeres, y los llamaba al orden si había peleas y conflictos entre unos y otros. D. Teolindo era muy liberal con los niños. Recuerdo que cuando me confesaba nunca me decía nada y me despachaba rápido diciendo que rezase tres Aves Marías.

\section{¿Te gustaba ir a la escuela? ¿Y estudiar?}

Lo cierto es que yo siempre me recuerdo en la escuela. Supongo que casi desde que nací mi madre me llevaría con ella. Desde la casa no había que salir para ir al local donde estaba la escuela, pues había una puerta interior que comunicaba con ella. Así que se podía decir que la escuela era mi medio natural. Me gustaba leer en voz alta, los dictados, las redacciones, salir al encerado a escribir, o hacer cuentas. Mi madre, que dividía la clase en pequeños, medianos y mayores, que correspondían más o menos al nivel de instrucción que teníamos, solía utilizar un método bastante activo, y bastante colectivo. Por ejemplo, para el dictado de los medianos, cada día uno salía a escribir al encerado y el resto levantaba la mano si pensaba que había escrito algo mal. Quizás lo más peliagudo era empezar a escribir con una pluma, que había que mojar en un tintero. Recuerdo las reprimendas que nos daba porque cuando caía una gota en el cuadernillo no se nos ocurría mejor idea que intentar disimularla frotando con el dedo, así que en bastantes casos terminábamos haciendo un agujero en el papel. También recuerdo la preocupación de los mayores cuando tenían que escribir y dibujar en un cuaderno especial que se presentaba al inspector cuando venía a visitar la escuela. 
Y lo nerviosos que nos poníamos todos con su visita, incluida mi madre. Menos mal que venía muy poco.

¿Cuáles fueron las primeras experiencias de injustica que viviste en la escuela? ¿Tuvieron algo que ver con los efectos de la enseñanza escolar en la población rural de la que formabas parte?

No sé si yo utilizaría el término injusticia para referirme a lo que fui percibiendo al irme haciendo mayor siendo niña. Lo cierto es que me di cuenta de que al resto de mis compañeros y amigos no les interesaban ciertas cosas que a mí sí. Por ejemplo, a mí me gustaba mucho cuando mi madre nos mandaba leer un libro que se titulaba El campo, pero a ellos no. Un día se me ocurrió preguntarles por qué no les interesaba y me contestaron que no les interesaba porque estaba equivocado, ya que las faenas agrícolas que sus familiares realizaban, y a las que ellos muchas veces ayudaban, no se hacían como decía el libro. Caí en la cuenta de que efectivamente aquel campo del libro no era el campo gallego, sino el de Castilla. Tampoco les interesaba leer cuando mi madre nos ponía a leer alrededor de su mesa un libro que se llamaba El mundo, mundo aquí se refería a un enorme baúl de viaje, para recorrer el mundo. El libro estaba formado por relatos escritos con una escritura que imitaba la manual de creciente dificultad. Me di cuenta de que ellos pensaban que ya les era suficiente aprender a leer bien una letra caligráfica normal.

En la escuela había libros de autores clásicos, entre ellos Los cuentos de Gulliver, Corazón de Amicis, Robinson Crusoe, El libro de la selva de Kipling, los relatos de Julio Verne etc., que a mí me fascinaban, pero que solamente a alguna de mis compañeras les interesaban, y los leían. A los muchachos les gustaban mucho los trabajos manuales, y hacían carros y arados en madera preciosos. Yo no entendía bien por qué las niñas no podíamos hacerlos, pero mi madre decía que lo mejor era que no utilizásemos navajas. En fin, nos tocaba hacer algo de costura que encontraba que era mucho más aburrida. Fue bastante más tarde cuando yo misma ejercí de maestra cuando me di cuenta de la distancia enorme que había entre la enseñanza escolar y el modo de vida rural.

Supongo que para hacer el bachillerato tuviste que dejar la Ulfe.

Sí, me fui a Chantada al Colegio de las Mercedarias. Eso supuso un cambio importante no solo para mí sino también para mi familia. Mi 
padre dejó de ser labrador para reconvertirse en relojero en Chantada, oficio que según dicen aprendió rápidamente, ya que era un verdadero «manitas». Y se convirtió en un conocido relojero. Mi madre tres años después pidió traslado y se vino también a una escuela que estaba muy cerquita de Chantada. Entre tanto yo estuve interna en el colegio tres años, y me costó bastante adaptarme, pese a que mi padre venía a verme con frecuencia y a que cuando hacía buen tiempo los fines de semana me permitían ir a A Ulfe con él. A Ulfe solo distaba seis kilómetros de Chantada pero entonces parecía una distancia respetable. Casi no había coches así que íbamos andando.

\section{¿Y cómo era la enseñanza en las Mercedarias?}

Por lo que recuerdo, la enseñanza, sobre todo la que impartían las monjas, no era muy buena y debíamos de memorizar todo, sin entender mucho. Pero pronto vinieron dos licenciados asturianos, un profesor de matemáticas y una profesora de Física y Química, que nos daban buenas clases. También tenían cuadros de honor de aplicación y buen comportamiento que cambiaban cada mes. Yo parece que estaba enchufada y aparecía con bastante frecuencia en ambos; mis amigas decían que el de buena conducta no lo merecía demasiado. Lo mejor eran las amigas, pues en esos años hacíamos algunas inocentes trastadas y nos lo pasábamos bien. Siendo ya adolescente, supongo que tendría unos 13 años, las monjas cuando se acercaba el verano no nos dejaban salir después de la cena, que era temprano. Así que saltábamos por la ventana y nos íbamos a dar una vuelta al centro de Chantada para encontrarnos con nuestras compañeras externas. Bajar por la ventana no era difícil, pero subir era un problema. Las otras compañeras eran delgadas, pero yo estaba gordita y era alta, así que la primera vez, yo ayudé a que las otras subieran y cuando quisieron subirme a mí no pudieron. Les dije que avisaran a sor María, que era la sacristana y buenísima persona para que me abriese la puerta. No sé qué disculpa inventamos, pero pienso que se daba cuenta de todo. A partir de ahí la primera que subía era yo. Las monjas eran buena gente y tenían bastante paciencia con nosotras. Nos examinábamos por libre en el Instituto Otero Pedrayo de Orense. También preparé Magisterio en las monjas y me examiné por libre en la Escuela Normal de Orense. 


\section{¿Cuándo decidiste que querías ser maestra y por qué?}

Lo cierto es que no recuerdo haber tomado esa decisión. Como mi abuelo materno y mi madre eran maestros parecía que era algo normal que yo siguiese ese camino, pues era una profesión corta. Y aunque teníamos huerta, gallinas, conejos y mi padre podría traer otras cosas de casa de los abuelos, el sueldo de maestra era pequeño. Por entonces había además la posibilidad, si tu padre o tu madre eran maestros, de permutar la escuela que tú obtuvieses en propiedad por la de ellos, en este caso la de mi madre. Esta posibilidad no era nada desdeñable, dado que, para estar en una villa, o muy cerca de ella, se tenían que pasar muchos años ejerciendo en una escuela rural. Así que mis padres veían que yo a los 18 años podía estar ejerciendo prácticamente en Chantada.

\section{Pero, no parece que siguieses ese camino...}

Creo que el que más se disgustó con esa decisión de que quisiera seguir estudios universitarios, y esa sí ya fue una decisión mía, fue mi padre. Mi madre me apoyó inmediatamente. Antes hice las oposiciones a Magisterio y estuve ejerciendo dos años en una escuela rural que estaba a cuatro kilómetros de Palas de Rey. Me lo pasaba muy bien con las niñas y niños, y la experiencia de mi madre me ayudó mucho y también contar con la ayuda de uno de los niños mayores, Antonio Orozco, que me permitió poner en práctica algo parecido a la enseñanza mutua. Antonio era muy inteligente y aplicado, y le encantaba estudiar, así que me ayudaba con los de grado medio. Hablé con sus padres, y aunque su padre se resistía porque era el primogénito y quería que se quedase en la casa, de nuevo con el apoyo de la madre, me permitieron prepararlo para primero e ingreso de bachillerato. Luego se licenció en Químicas y aprobó las oposiciones a catedrático de instituto. Pero lo cierto es que me sentía un tanto sola, pese a que tenía amenas charlas con el abuelo de la casa en la que me hospedaba cuando salía por la tarde e iba a encontrarme con él adonde estaba cuidando las vacas. Charlábamos de muchas cosas, de los problemas del campo, de su nieto que iba a hacer la mili, y al que yo daba clase antes de cenar, e incluso sobre algunos de los llamados huidos de la guerra. Todavía quedaba alguno en la zona, y cuando hacía frío se quedaba en la entrada de la escuela. Parece que le había dicho que no se atreviese a molestarme. Consideraba que a mí con 17 años podría darme un gran susto. Y seguramente fuera así. No tuve 
problemas con la disciplina, algo que preocupaba mucho a mis compañeros. Y por lo que me contaban los niños y niñas, los maestros y maestras seguían recurriendo a los castigos físicos. A mí me gustaba estudiar, así que decidí ir a la Universidad de Santiago y seguir estudios.

¿Qué cambios supuso para ti la Universidad? ¿Se cumplieron las expectativas que tenías respecto a ella?

Sin duda las expectativas que tenía de la universidad se cumplieron. Estudié mucho en Santiago, y me lo pasé también muy bien. Me gustaron las clases y me encantó la ciudad. Tuve profesores como Río Barja, Moreno Báez, Manteiga, Moralejo, Otero Túñez, Alonso del Real, Eiras Roel, todos ellos buenos profesionales, y muchos con un amplio reconocimiento en el mundo académico. A principios de los sesenta el ambiente en Santiago era muy estimulante. Por ponerte algunos ejemplos, asistíamos al cine club, íbamos a los seminarios de filosofía que hacía Manteiga que eran clandestinos; Moreno Báez los sábados por la mañana nos hacía audiciones de música clásica. Y luego estaban las charlas con los amigos y amigas, y los paseos por esa única ciudad, y por los parques que la rodean. En fin, muchas experiencias nuevas y muy satisfactorias.

Después de hacer los dos cursos de Comunes en Santiago te fuiste a Madrid a hacer Pedagogía.

Sí, para hacer la especialidad de Pedagogía había que ir a Madrid. Así que mi madre me buscó un Colegio Mayor, pues creo recordar que fue el primer curso que era necesario tener residencia en Madrid para poder matricularse, lo que hizo que perdiera varios compañeros que iban a venir a hacer la especialidad a Madrid, que tuvieron que ir a Valencia o a otras ciudades a hacer otras especialidades. A mi llegada, en 1965, eché mucho en falta la vida que llevaba en Santiago.

El profesorado de la especialidad de Pedagogía era, en términos generales, mucho peor que el de Santiago. Del primer curso solo recuerdo a Yela que nos habló de las virtudes del universitario, una visión que luego vi que era totalmente romántica, pero que en aquel momento nos dio algo de ánimo. Para qué hablar de Romero, que parece había logrado la cátedra como alférez provisional y que, según decían, había compuesto la letra de Prietas las filas. En fin, curiosamente los menos malos eran una teresiana, Ángeles Galino, que nos dio un cuatrimestre historia 
de la educación, luego mandó a un ayudante, y Víctor García Hoz, que era del Opus y nos daba educación personalizada. Pero tuve la suerte de que se incorporó, en segundo de especialidad, Mercedes Valcarce, de la cátedra de Pinillos, que había estado estudiando con Piaget en Suiza, y nos daba Psicología del niño. Fue como una bocanada de aire fresco, pues además de las clases nos hacía leer libros interesantes no solo de Piaget, también de Erich Fromm, Margaret Mead, René Spitz, etc. Pude hacer la Tesina con ella y fue quien me animó a irme al extranjero cuando terminé. Así que en vistas de que tenía claro que la Pedagogía no me interesaba, y que no quería ser inspectora de enseñanza, algo que para una maestra como mi madre suponía el éxito total, pedí una beca de la UNESCO y me fui a París, al principio a hacer psico-socio-pedagogía — ¡hay que ver lo modernos que eran entonces en el INCIE! - y luego sociología.

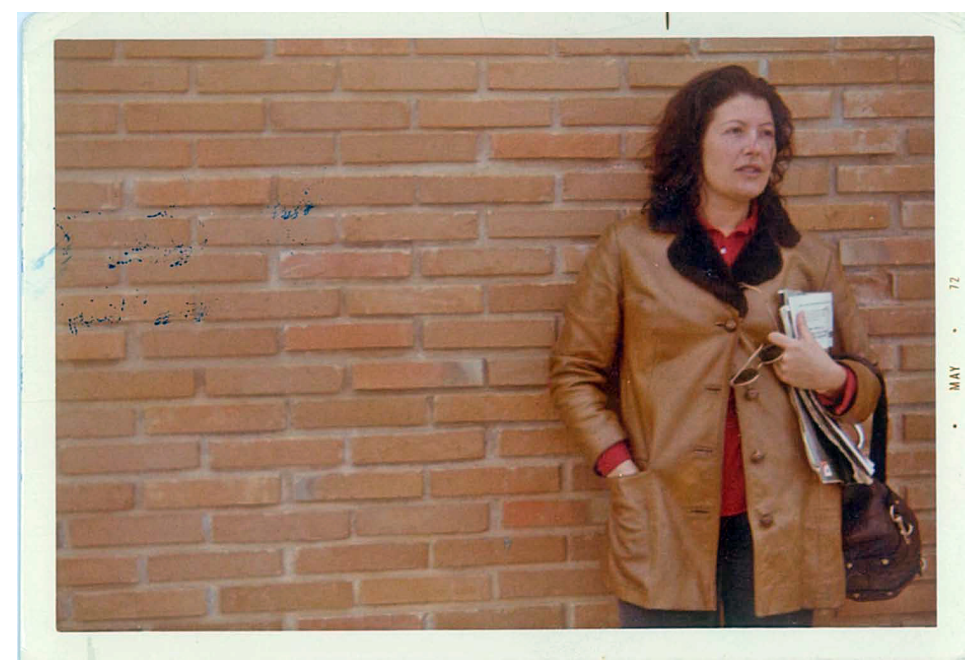

Julia Varela en Madrid, a finales de los 60.

¿Cómo era el ambiente que encontraste en Madrid a mediados de los sesenta?

Esos años fueron unos años muy movidos, tanto desde el punto de vista político como cultural. Llegué justo el curso que expulsaron de la Universidad de Madrid a algunos profesores, entre ellos a Aranguren, Tierno y García Calvo... Durante el curso siguiente hubo movilizaciones estudiantiles y tuvo lugar la creación del Sindicato Democrático de Estudiantes 
Universitarios de Madrid (SDEUM). Corrimos delante de los grises pidiendo la democratización del país y de la universidad. Los aires de mayo del 68 también estaban llegando. La cafetería era un verdadero hervidero de informaciones tanto culturales como políticas. Conviene no olvidar que en el 69 la dictadura decretó el estado de excepción.

Empecé a hacer amigas y amigos. Entonces en la Facultad de Filosofía y Letras había un ambiente muy cosmopolita y bullicioso, estudiantes de todas partes de España, e inicié mi formación política, aunque debo decir un tanto tibiamente, leyendo libros clandestinos que me pasaban, quizás en parte porque empecé por Materialismo y empiriocriticismo de Lenin que me resultó difícil de digerir. Algunos leíamos con fruición un libro de Benjamin Farrington La rebelión de Epicuro, y El miedo a la libertad de Erich Fromm. En relación con ese clima que entonces se vivía dentro y fuera de las aulas, hay que señalar que en el Colegio Mayor Landirás, en el que estaba, había un cine club famoso que dirigía, entre otros, Josefina Molina que estaba también en el Colegio. Y que cuando vino Raimon a cantar a la Facultad de Económicas, en mayo del 68, cantó también en el Landirás. En su cafetería cantábamos también por entonces con frecuencia canciones de Chicho Sánchez Ferlosio: Gallo rojo, gallo negro, Ay Carmela, y otras. No solo el Landirás era un Colegio en el que se realizaban muchas actividades culturales, también en el San Juan Evangelista que estaba al lado y en otros cercanos. No milité en ningún partido político, aunque tenía amigas y amigos que sí lo hacían. Y, por supuesto, no es este el momento de hablar de lo que supuso para mí el descubrimiento de la ciudad de Madrid.

¿Por qué te fuiste a París y qué cambios notaste respecto a Madrid?

En 1970 se había fundado el Centro Nacional de Investigaciones para el Desarrollo de la Educación (CENIDE), para poner en marcha la Ley de educación del 70, conocida como la Ley Villar Palasí. En esa puesta en marcha intervino también la UNESCO, el Banco Mundial, y alguna institución más que ahora no recuerdo. El caso es que vinieron al CENIDE, que tenía su sede en Madrid en la Ciudad Universitaria, especialistas franceses en educación, entre ellos Jacques Bousquet que fue director del CENIDE en sus primeros años, y Michel Lobrot. Yo entré en contacto con ellos, y en parte gracias al francés, que estaba aprendiendo, conseguí una beca de la UNESCO que, como ya dije, me permitió ir a 
París y cambió mi vida, pues allí seguí varios años estudiando y formándome al principio en educación, y psicología, y luego en sociología, y allí presenté mi Tesis en sociología de la educación.

\section{¿Fuiste directamente a la Universidad de Vincennes?}

Con la beca de la UNESCO fui a los cursos sobre pedagogía institucional que impartían Michel Lobrot, y Jacques Ardoino en Vincennes. A René Lourau lo conocí más tarde. Hice también dinámica de grupo. Y la tutora de la Unesco me puso en contacto con un grupo de psicodrama, al que asistí durante ese curso. En fin, todo resultaba nuevo para mí. Pero tampoco tenía muy claro que quisiese seguir en el Departamento de Educación de Vincennes, aunque me propuse seguir en París. Así que pedí una beca del Gobierno francés que me concedieron para el curso siguiente, y decidí seguir haciendo educación y psicología — había hecho los cursos de la Escuela de psicología que estaba en la calle San Bernardo en Madrid, pues entonces todavía no había licenciatura de psicología- y me matriculé en la Sorbona.

En enero empecé mi relación con Fernando Álvarez-Uría que además de hacer estudios de psicología en la Sorbona estaba estudiando sociología en Vincennes. Me animó a que fuese a la Universidad de Vincennes a hacer estudios de sociología. Lo cierto es que el profesorado de la Sorbona, salvo alguna excepción, tampoco era mejor que el de Madrid, así que no lo dudé. Vincennes era una Universidad creada justo después de mayo del 68 con un nuevo sistema de enseñanza, y a la que también podían acceder, tras un examen de conocimientos generales, personas que no habían hecho el bachillerato.

El Departamento de Sociología contaba con un grupo de profesores excepcional... Había un currículum abierto, elección de profesores, materias y horarios. Y se podía hacer un determinado número de créditos en otras licenciaturas. No había notas, solo apto o no apto; ni exámenes. Las calificaciones eran el resultado de trabajos realizados en grupo o individualmente, y presentados en clase. Con ese motivo hicimos amigos franceses, españoles, brasileños y de otros países.

Los que nos matriculábamos en Sociología podíamos hacer un determinado número de créditos en Económicas, en Filosofía, en Pedagogía, en otras licenciaturas. 
¿Recuerdas quiénes eran los profesores que te dieron clase?

En el Departamento de Sociología había tendencias muy distintas, y algunos de los profesores que nos dieron clase ya eran conocidos, entre ellos Nikos Poutlanzas, Michael Löwy, Robert Castel, Jean-Claude Passeron... Y otros menos conocidos como Michel Meyer, Bernard Conein, los Duroux..., que eran también muy buenos profesores.

Siempre decimos que allí nos enseñaron a leer. Michel Meyer, que impartía una asignatura titulada Introducción al análisis del discurso, fue especialmente importante en este sentido. Te mostraba en la práctica, cuando exponías, cómo debías distanciarte de lo que leías y poder entender lo que realmente se explicaba en el libro. Nos estimulaba a conocer la lógica interna de desarrollo del libro, no a hacer resúmenes por capítulos, en fin, a saber de qué iba el libro en profundidad, qué procesos y qué dimensiones ponía el autor en conexión, por qué y para qué lo escribía, qué limitaciones tenía, en qué corriente de pensamiento se situaba.

¿Cómo influyó en tu formación que hubiera profesores de tendencias teóricas y metodológicas distintas?

Pienso que fue muy importante, pues, aunque los cursos que elegimos los impartían profesores que eran de izquierdas, tuvimos la suerte de que unos nos explicaran el marxismo, otros el funcionalismo, otros el positivismo, y así pudimos trazar un mapa del campo intelectual bastante claro. Conocimos sus antagonismos, los diferentes sistemas conceptuales que habían elaborado distintos autores, sus modelos de análisis. Nos ayudaron a comprender que el campo intelectual era el resultado de enfrentamientos y conflictos, que no estaba exento de relaciones de poder.

Creo recordar que además era una universidad en la que se desarrollaban muchas actividades.

Sí, además de tener una biblioteca muy bien dotada, siempre había múltiples actividades, desde conferencias a cine, pasando por conciertos, a las que venía gente famosa muchas veces. Estaban además los mítines que hacían los estudiantes de los distintos partidos de izquierda, algunos para reivindicar cambios de planes, más autonomía para los estudiantes, aunque tenían mucha, etc. Todos los días se vendía Charlie 
Hebdo, Liberation, Le Monde... En fin, se podría seguir hablando largo rato de esta universidad ubicada en el bosque de Vincennes, que creo es el mayor espacio verde de París, con lago, zoo, y con su famoso Château.

¿La formación que recibiste en Vincennes te ayudó a elegir la genealogía como método de conocimiento y garantía para realizar una investigación crítica?

Sin duda, pues muchos de los profesores que tuvimos hacían sociología histórica. No solo Robert Castel, quien luego dirigió el DEA y la Tesis de Fernando, sino también Bernard Conein que nos hizo trabajar en la Biblioteca Histórica de París. Y otros profesores que no hacían sociología histórica, como Paul de Gaudemar, Poulantzas o Lowy nos hicieron leer a los cásicos, Marx, Weber, Durkheim, que se servían de la historia en sus investigaciones.

Los libros que estábamos leyendo — de Durkheim también La división social del trabajo, de Marx, El 18 Brumario, de Castel El orden psiquiátrico-, nos parecían libros muy interesantes. Y además hay que tener en cuenta que nuestros directores de Tesis estaban trabajando en esa dirección.

Por otra parte, tanto tú como Fernando conocisteis a Michel Foucault, lo que también influyó en vuestros trabajos.

Sí, yo había comprado Las palabras y las cosas de Michel Foucault, cuando hacía la tesis de Pedagogía sobre los vocabularios, más concretamente sobre los vocabularios de orientación científica, pues pensaba por el título que tendría algo que ver con lo que estaba haciendo. Y sin duda tenía algo que ver y cambió la orientación de mi trabajo que era muy positivista, pero yo quedé fascinada por ese libro, y luego seguí leyendo cosas suyas. Se publicó, en 1975, su libro Vigilar y Castigar, que me interesó especialmente pues estaba empezando a hacer la Tesis de sociología de la educación...

Fernando y yo fuimos a su Seminario del Colegio de Francia varios cursos, e incluso llegamos a conocerlo personalmente a través de Robert Castel. De hecho, el primer libro que publicamos en la Colección Genealogía del poder de Ediciones La Piqueta, cuya propietaria era María Fuentetaja, fue la Microfísica del poder con textos suyos. 


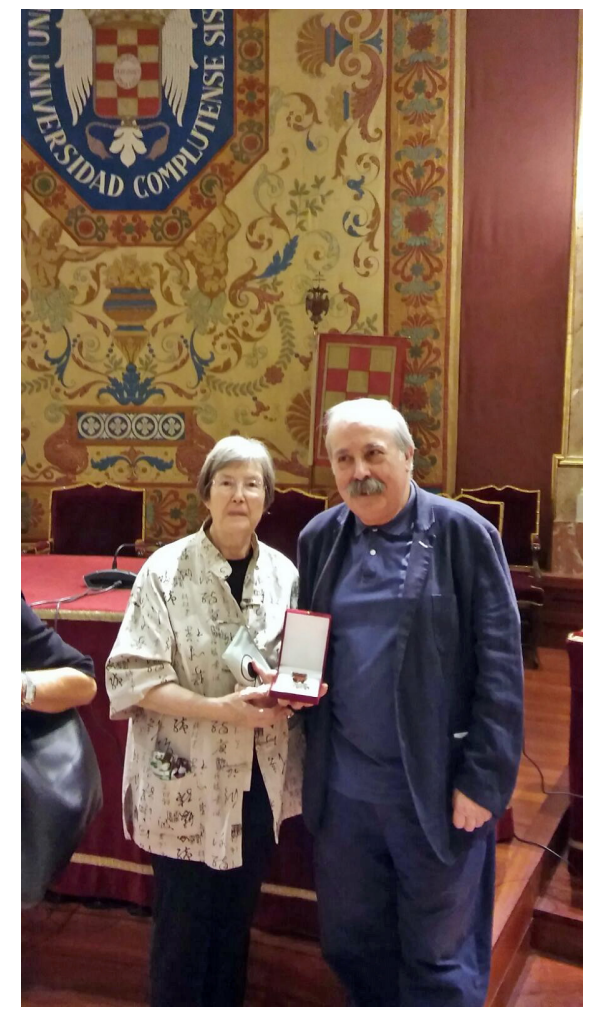

Junto a Fernando Álvarez-Uría en el Paraninfo de la UCM, 2018.

Quizás convenga que volvamos de nuevo a Vincennes y a los clásicos de la sociología, pues tú sueles decir que es necesario leer a los clásicos.

Sí, porque los clásicos de las ciencias sociales resultan fascinantes, pues eran gente que tenían conocimientos muy amplios, habían hecho varias especialidades, y sin duda son mucho más interesantes que nosotros. E incluso me atrevería a decir que más actuales en muchos sentidos.

Paul de Gaudemar fue mi director del DEA y luego de la Tesis que fue publicada en La Piqueta con el título de Modos de Educación en la España de la Contrarreforma. Era un durkheimiano que conocía muy bien a los clásicos y tenía una visión no evolucionista de Durkheim. Cuando volvimos a Madrid publicamos en la Colección Genealogía del Poder L'évolution pedagogique en France de Durkheim, con el título, Historia de 
la educación y las doctrinas pedagógicas. Pierre Bourdieu consideraba este libro un modelo de sociología histórica. De Gaudemar nos hizo leer ese libro y comentarlo en detalle. Me hizo apreciar especialmente los trabajos de Durkheim. Seguíamos también los seminarios de Pierre Bourdieu y Jean-Claude Passeron en L'Êcole Pratique d'Hautes Ëtudes, en donde conocimos a Claude Grignon y Jean-Claude Chamboredon. Bourdieu apreciaba mucho la sociología histórica, aunque él no hizo trabajos en esa dirección. Como sabes publicaron en la Colección Le Sens Commun, que dirigía Bourdieu, en Ediciones Minuit, libros importantes de educación como Los herederos: los estudiantes y la cultura, y La reproducción. Esta última obra acababa de ser publicada en 1970.

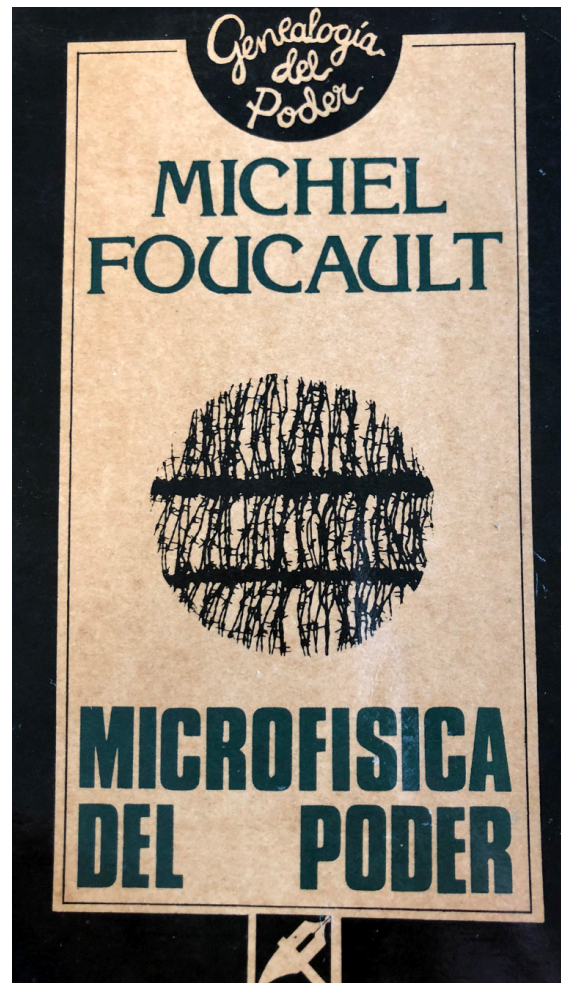

Cubierta del libro Microfísica del poder.

Todas esas fuentes fueron muy importantes para nosotros, y nos hicieron plantearnos qué metodología debíamos elegir para realizar nuestros propios trabajos, empezando por la Tesis. 
¿Qué virtualidades encontrasteis en la sociología histórica, una metodología que exige un arduo trabajo de archivo, para decantaros por ella?

En primer lugar, el papel que confería a la historia. Nos hicieron comprender que no hay que confundir el presente con lo contemporáneo. En el presente están incidiendo toda una serie de procesos anteriores que han ido transformándose. Si no somos conscientes de esto no podemos entender bien lo que está pasando en la actualidad. Vivimos en una especie de presentismo que no nos ayuda a explicar las cosas que acontecen.

En segundo lugar, permitía romper con el auge que empezaba a tener entonces la visión de la sociedad formada por individuos, a través del peso que iba adquiriendo en Europa la sociología norteamericana, liderada sobre todo por Talcott Parsons. Para todos los profesores que habíamos elegido, la sociedad estaba formada por clases sociales, por distintos grupos sociales, que tenían intereses distintos, una sociedad en la que existían relaciones de poder, relaciones de fuerza.

Y, por último, algo que está ligado con todo lo anterior, que es la importancia de lo social. En los trabajos de estos autores a los que me estoy refiriendo, y de otros que conocí un poco más tarde como Norbert Elias y su libro El proceso de la civilización, gracias a De Gaudemar, o Puericultura y moral de clase de Luc Boltanski, gracias al grupo de Bourdieu y Passeron, se tiene muy en cuenta que somos seres sociales, que no somos seres individuales aislados.

Me interesaron los trabajos de Norbert Elias, y concretamente El proceso de la civilización. En este libro estudia la sociogénesis de las llamadas funciones naturales; es decir, a través de qué normas, de qué reglas, que varían según las épocas históricas y las clases sociales, y que están atravesadas por relaciones de poder, nos relacionamos y conformamos individualmente. Es un libro muy interesante para los que nos ocupamos de la educación, pues esas reglas no son otras sino aquellas que denominamos reglas de urbanidad o de buena educación, y deja claro hasta que punto dependemos unos seres humanos de otros en nuestras formas de ver, de pensar y de sentir. 
Todos esos autores a los que te refieres, y por supuesto Norbert Elias, ofrecen una perspectiva muy distinta de las que dominaban entonces en sociología de la educación en España.

Sí, entonces las perspectivas dominantes eran un cierto marxismo y el funcionalismo, representados sobre todo el primero por Althusser y la escuela como un aparato ideológico de Estado, y el segundo por Parsons que entendía la escuela predominantemente como un sistema de adaptación y de jerarquización de los individuos al orden social. Norbert Elias, en algún sitio ha dicho que tanto Althusser como Parsons proyectaban su postura política excesivamente en el campo intelectual, en los trabajos que realizaban, y que por lo tanto esos trabajos eran demasiado ideológicos.

¿Cómo fue el retorno a España? Por lo que conozco de tus trabajos y entrevistas te interesaba especialmente favorecer la democratización de las instituciones, y más concretamente la escuela y la universidad.

Volvimos definitivamente a Madrid, a finales de los 70, justo en los años de la Transición, y nos encontramos con una gran efervescencia política y social. Mucha gente quería cambiar las cosas, romper con el franquismo. Nuestra formación nos hacía especialmente sensibles al cambio social, al cambio en las instituciones. De ahí que nuestro trabajo, tanto el de Fernando, como el mío, estuviese vinculado a determinadas demandas sociales que entonces eran fuertes.

En mi caso no solo estaban los movimientos de renovación pedagógica, sino que además los distintos grupos políticos, y los sindicatos de profesores, estaban discutiendo programas educativos alternativos. Había esa idea de que la educación iba a ser muy importante en la transformación del país, que era necesaria una educación formal distinta, en tanto que uno de los pilares fundamentales de la democracia.

El problema era que no toda la gente de izquierdas y progresista se ponía de acuerdo en cómo promover ese cambio. Por poner un ejemplo. A finales de los 70 hubo una contra-conferencia de la OTAN, en la que nos reunimos gente distinta, sobre todo representantes de partidos de izquierdas: del Bloque, de Herri Batasuna, Liga Comunista Revolucionaria, Movimiento Comunista, Consejistas, Partido Radical, etc. A nosotros creo que nos invitaron porque pensaron que podríamos mediar para 
que viniese Foucault. Lo cierto es que lo intentamos a través de Robert Castel que era amigo suyo, pero no vino. En las reuniones defendimos la necesidad de promover el cambio institucional, la importancia de democratizar la escuela, las cárceles, los manicomios..., pues pensábamos que no se podía cambiar la sociedad únicamente a través de la toma del palacio de invierno, que era preciso empezar por la base, cambiar hábitos, costumbres.... en fin, luchar contra el estalinismo y contra el neoliberalismo individualista.

Lo cierto es que para la mayoría de los partidos políticos presentes la lucha política y la economía eran lo más importante, y lo social, las relaciones sociales, lo secundario. Tenían una concepción del funcionamiento social bastante rígida y en ocasiones estalinista.

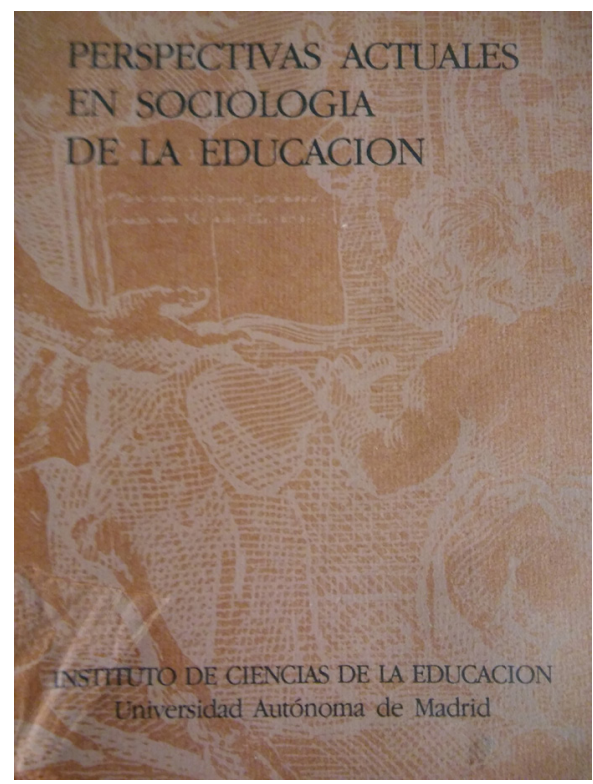

Cubierta del libro Perspectivas actuales de sociología de la educación.

Creo recordar que a principios de los años 80 coordinaste el Primer Congreso Internacional de Sociología de la Educación en el ICE de la Universidad Autónoma de Madrid, y poco después publicaste Modos de educación en la España de la Contrarreforma.

Sí, celebramos en el ICE de la Universidad Autónoma de Madrid el Primer Congreso Internacional de Sociología de la Educación los días 9, 
10 y 11 de marzo de 1981, que contó con una gran afluencia de profesionales de la enseñanza y con un importante colectivo de congresistas. Las ponencias se recogieron en un libro Perspectivas actuales de sociología de la educación, publicado por el ICE en 1983. Y precisamente ese mismo año se publicó también Modos de educación. Como ya señalé, para bastantes profesionales de la enseñanza, sobre todo diría profesores de enseñanza media, existía la convicción de que el sistema educativo de la dictadura era incompatible con la democracia. En las manifestaciones a favor de la reforma era frecuente escuchar: «El hijo del obrero, a la Universidad».

¿Tu trabajo empezó a ser conocido por profesionales de la enseñanza?

Me parece que fue un decreto de 1984 el que reguló la creación y funcionamiento de los CEPs. Pero ya en los setenta me habían invitado a bastantes de las actividades que hacían los movimientos de renovación pedagógica, y luego también los controvertidos CEPs. Si no recuerdo mal les hablaba sobre todo de los trabajos relacionados con la educación escritos por Bourdieu y Passeron, Foucault, Bernstein... Y no de mis trabajos.

A lo que tendría que añadir que a los profesionales que asistían a esos cursos y seminarios les interesaban más las experiencias ligadas a «la escuela nueva», los libros y las alternativas educativas promovidas por Freinet, Freire, Rosa Sensat, Neill, Illich y muchos otros que rompían con la enseñanza tradicional. Ya empezaba a ponerse de moda esa corriente que sigue pujante en la actualidad del juego, la creatividad... Corriente que tanto Basil Bernstein, como Claude Grignon han cuestionado en parte en lo que se refiere a sus efectos sobre las niñas y niños de las clases populares.

Si pasamos ahora a los primeros libros que publicaste, Modos de Educación en la España de la Contrarreforma, Arqueología de la Escuela y Nacimiento de la mujer burguesa, los tres son de sociología histórica. Empezando por el primero ¿qué aportaciones crees que encierra?

En primer lugar, conviene aclarar que el trabajo intelectual es siempre un trabajo colectivo. Y si en Modos de educación me planteé hacer un trabajo histórico-comparativo entre el tipo de educación que recibían los hijos de los distintos grupos sociales del siglo XVI y XVII es porque 
había leído a los clásicos. En este sentido, me ayudó mucho el libro de Durkheim La evolución pedagógica en Francia, especialmente cuando se refiere a la enseñanza de los jesuitas.

De ahí que me centrase en investigar, a través de un trabajo de archivo, cómo era la educación de la nobleza, del mediano estado y de los pobres. Otro referente para mi trabajo fue también Marx. El concepto modos de educación hace referencia a modos de producción, si bien a mí me interesaban especialmente los cambios que afectaban a la esfera social.

Me gustaría preguntarte, aunque no sé si es fácil la respuesta, cómo procedes cuando investigas.

El punto de partida es un problema social, responder a una demanda social. Tienes que adoptar una posición específica respecto a lo que piensas del funcionamiento del mundo social, pues eso ya va a marcar todo lo que hagas a continuación, pero luego también es importante los conceptos que vas a utilizar, algunos ya vienen dados por las fuentes que has seleccionado, clase social, relaciones de poder, etc. Lo ideal es que llegues a elaborar tus propios conceptos, pero eso es bien difícil. Una vez que ya has recogido bastante material de los archivos en torno al objeto que quieres investigar, tienes que ver cómo lo organizas. Al menos yo no puedo trabajar si no tengo a partir de un cierto momento un esquema de desarrollo del trabajo. Por ejemplo, para hacer la comparación entre la educación que recibían los tres grupos sociales elegidos, me parecieron relevantes tres aspectos a los que se referían los materiales que tenía: el cuidado del alma, el cultivo del ingenio y la destreza del cuerpo. En esa selección también jugaban un cierto papel las fuentes, por ejemplo la importancia que daba Foucault al cuerpo en Vigilar y castigar me hizo especialmente sensible a esa dimensión. También es importante establecer una cierta periodización a partir de los cambios y rupturas que se produzcan.

¿A qué resultados llegaste? Creo que fue en ese libro donde percibiste que la educación es un dispositivo muy importante tanto en lo que se refiere a las formas de subjetivación individuales, como a las identidades sociales.

Efectivamente, lo primero que me llamó la atención fue que los tipos de educación, que promulgaban los distintos tratadistas y textos de esa 
época, desde finales de la Edad Media, eran enormemente diferentes. De ahí que algunos historiadores se refieran posteriormente a una sociedad formada por estamentos.

No es cuestión de resumir aquí el libro. En todo caso se mostraba claramente que la educación que debía de recibir el grupo dominante en esa época, la nobleza, sobre todo la nobleza cortesana, abarcaba lenguas clásicas, de ahí que tuviese un profesor de lenguas - también de latín que era entonces la lengua universal-, pero los nobles también tenían maestros de buenas maneras, de armas, de baile. Los maestros tenían que enseñar deleitando, y mantener un esmerado cuidado del alma, del cultivo del ingenio y de la destreza del cuerpo destinados a conferir a esos nobles cortesanos, y especialmente al príncipe, cualidades sobresalientes y brillantes. Norbert Elias en La sociedad cortesana muestra como los ceremoniales y etiqueta de la Corte, en este caso la francesa de Luis XIV, estaban destinados a dotarlos de un especial brillo y esplendor, lo que por otra parte implicaba que adquiriesen un fuerte autocontrol para distinguirse en sus formas de hablar, de vestirse, de moverse, en fin, de relacionarse, tanto del estado medio, como sobre todo de las clases populares.

En el libro concedes una especial atención a los colegios de jesuitas y a su enseñanza en la formación del estado medio, de la futura burguesía.

Los jesuitas son los artífices de un nuevo modo de educación a través de sus colegios que constituyen los antecedentes de las instituciones escolares que nosotros conocimos, y que incluso continúan teniendo un cierto peso en la actualidad. Los jesuitas pusieron en marcha un nuevo modo de educación destinado a formar una nueva nobleza, la nueva nobleza de las letras y de las virtudes católicas.

La pedagogía jesuítica fue muy innovadora porque puso en marcha un sistema escolar uniforme en todos sus colegios. La Ratio Studiorum contiene el régimen que tenían que seguir los estudios en sus colegios, la formación específica de los profesores, qué debían enseñar, cómo debían hacerlo, qué castigos físicos debían aplicar y quién tenía que hacerlo, etc.

Organizaban la clase en decurias, grupos de diez, según el nivel del conocimiento del latín, siempre en competición unas con otras. Cultivan 
el ingenio de sus colegiales a través de la enseñanza del latín, la lengua universal de la época, para lo que utilizaban variados ejercicios. No se olvidaban del cuidado del alma, la doctrina cristiana, la confesión, los ejercicios espirituales. Y no se olvidaban tampoco del cultivo del cuerpo, pues no solo su sistema de educación suponía un control fuerte del cuerpo, silencio, reposo, etc., sino que se sirvieron también de exámenes frecuentes, y algunos de ellos, los más importantes, con presencia de público, en donde se producían verdaderas luchas dialécticas entre unos y otros. Esa lid permanente implicaba premios, cuadros de honor, etc. Utilizaron algunas obras de teatro para conformar moral y cristianamente a sus colegiales. Todo este fuerte ceremonial estaba destinado a dotarlos de una hexis corporal específica. Creo que fue Durkheim quien dijo muy acertadamente que los colegiales dejaron de ser estudiantes, ya que perdieron todos sus derechos.

Me parece que no se deben olvidar los importantes cambios que se estaban produciendo desde finales de la Edad Media en las relaciones laborales, en el mundo del trabajo, y en la configuración social, las clases sociales, pero me interesa subrayar sobre todo que la enseñanza de los jesuitas jugó un importante papel socio-político al contribuir a conferir una identidad social específica a ese estado medio en ascenso que luego se llamó burguesía, que pudo acceder al poder político a finales del siglo XVIII, y convertirse en clase dominante, en la clase hegemónica.

Supongo que el programa educativo de los pobres será, valga la redundancia, mucho más pobre.

Una parte de los niños pobres fueron recogidos en albergues, seminarios, casas de doctrina, especialmente a partir de la Contrarreforma, aunque estas instituciones empezaron a funcionar antes. Vives escribió el influyente Tratado del socorro de los pobres. Es curioso que, con la Contrarreforma, se empobrecen los programas destinados a la enseñanza de los niños pobres. Hasta entonces, incluso algunos podían estudiar gramática latina, pero posteriormente algunas pragmáticas de Carlos III y Felipe IV les prohibieron este aprendizaje. Se los condena a una inferioridad lógica, ya que la gramática entonces no era lo que nosotros conocemos con ese nombre, sino un aprendizaje en profundidad para manejar bien el latín. Sus aprendizajes los destinan a los oficios. Se 
establece así una clara diferencia entre trabajo intelectual y trabajo manual. Y, por supuesto, tenían que aprender la doctrina cristiana, el catecismo de memoria, ir a la iglesia, ser buenos cristianos. Los accidentes de trabajo eran muy frecuentes, así que no solo por lo que se refiere al ingenio y al cuidado del alma, sino también a su aspecto físico y a su relación con el cuerpo, el vulgo se distancia cada vez más de las otras clases sociales.

Esos modos de educación aparecen legitimados en los textos de época, algunos de importantes humanistas.

Sí, entre ellos por Erasmo y por Vives, que se sirven de Platón. Platón, en la República, defiende que tiene que gobernar el que más sabe y obedecer el que es ignorante. Los modos de educación contribuyeron a formar naturalezas de oro, plata y hierro, a las que se refieren explícitamente los humanistas, a las que confieren propiedades distintas, en consonancia con programas de educación específicos. La educación fue uno de los instrumentos importantes para instituir un sistema social de jerarquización y de dominio.

Hay textos muy expresivos, recogidos en el libro, entre ellos uno de un jesuita, el P. Astete, cuyo catecismo estudié yo de pequeña, titulado El estudiante perfecto, que muestran quizás mejor que lo que he estado diciendo de qué cualidades tenían que dotarse los futuros componentes de la burguesía, cuál debía de ser su comportamiento, y, por supuesto, cómo no debían de tener tratos con el vulgo:

El estudiante perfecto debe de ser modesto, bien hablado, manso, cortés, devoto, callado, obediente, caritativo, estudioso, aprovechado, honesto y adornado de todas las virtudes; verdadero ángel, en oposición al estudiante inmodesto, deshonesto, liviano, hablador, jugador, vagabundo, desaprovechado, revoltoso, indevoto, mofador y de malas costumbres. El vestido, la forma de hablar, los movimientos del cuerpo, son voces que reflejan el interior del alma. El que va compuesto y honestamente vestido, va publicando sin hablar palabra que es santo, bueno, ejemplar, recogido y estudioso. El que va inmodesto, jugando de manos y guiñando ojos, contorneando el cuerpo, el cabello despeinado, los aladares largos, el vestido rozagante, los zapatos picados, las medias de color, y el 
ceñido profano va pregonando con el traje y movimientos que es liviano, inquieto, descuidado, de pocas letras y malas costumbres. El lenguaje ha de ser natural y no afectado, ni estudiado ni pulido, ni tosco o bronco o con impropiedades. El tono de voz natural y moderado, ni muy alto ni muy bajo, sin torcer la boca ni jugar de manos, el cuerpo ha de estar quieto y solo la lengua ha de hacer sus oficios sin contradicciones ni porfías. Los sentidos, ventanas del alma, han de estar siempre guardados, no irá a espectáculos públicos, comedias, bailes ni danzas, ni se detendrá en observar otras imágenes cualesquiera que la parte de su trabajo le inciten a la lujuria. No jugará juegos de manos, juegos de villanos, ni hará apuestas. No se perfumará ni acicalará, y por supuesto evitará cualquier contacto con el contaminante y grosero vulgo. No jugará a los naipes, ni menos irá a casa de garitos, ni a casas públicas. En ningún caso debe entrar a beber en tabernas, bodegones, mesones o hosterías, que son oficios de gente ruin, ajena al honor de su profesión. ${ }^{1}$

Si pasamos a Arqueología de la escuela, ¿qué te gustaría destacar de ese libro? Si te parece podríamos centrarnos en el capitulo primero, la maquinaria escolar, que es fundamental para todo el desarrollo ulterior.

Me parece muy bien, y creo que incluso me voy a referir especialmente a una de las piezas de esa maquinaria, la infancia, pues se adecúa bien a lo que quiero explicar ya que en Arqueología de la escuela continué investigando cómo se formaba y transformaba ese estado medio. Y fue a través del análisis de la infancia cómo se fueron perfilando las otras piezas del sistema escolar.

Quizá antes de entrar en el tema convenga decir que todos esos autores, a través sobre todo de Las formas elementales de la vida religiosa, y de Las palabras y las cosas y, más tarde, de varios libros de Norbert Elias, me llevaron a descubrir que existen toda una serie de conceptos fundamentales, de categorías de conocimiento, que orientan nuestra forma de conocer y de vivir. Las categorías de espacio, tiempo, jerarquía, causalidad... Una de ellas tiene que ver con la categoría de «identidad». Estas

\footnotetext{
1 Alonso de Andrade, El estudiante perfecto y sus obligaciones (Madrid: 1643), 203. Citado en Julia Varela, Modos de educación en la España de la Contrarreforma (Madrid: Ediciones de La Piqueta, 1983), 144.
} 
categorías vertebran toda nuestra vida, y son como una especie de andaderas gracias a las cuales nos movemos por el campo intelectual, son construcciones logradas a través de la historia, forman parte de un fondo común de conocimiento, y varían según las culturas, las épocas históricas, las clases sociales...

La categoría de identidad es por su formación una de las más modernas, ya que en la Edad Media no existía: los seres, las cosas, no eran idénticas a sí mismas, pues había poderes, Dios y el diablo estaban interviniendo constantemente en el mundo y transformando su apariencia. Por ejemplo, si consideramos la brujería se pensaba que una mujer podía transformarse y salir volando en una escoba hacia el aquelarre. Por eso cuando Foucault se refiere en Las palabras y las cosas a las distintas epistemes, a los distintos códigos que rigen el campo del saber, muestra cómo en la Edad Media regía un pensamiento mágico-mítico. La separación entre lo que luego denominamos natural y sobrenatural no tiene lugar hasta la Edad Moderna. Se le atribuye a Descartes con su obra El discurso del método la iniciación del pensamiento científico, que no es posible sin la adquisición de la categoría de identidad: cada cosa es idéntica a sí misma.

\section{¿Piensas que «la infancia» es una de esas categorías?}

Si no es una categoría en el sentido estricto es sin duda uno de los conceptos que articula nuestra forma de percibir y de vivir en el mundo. Quizá conviene comenzar diciendo que ciertos conceptos tales como familia, infancia, escuela, etc., suelen ser naturalizados con bastante frecuencia, y que es necesario evitar esa naturalización, pues tienen distintos sentidos, distintos significados, según los momentos históricos, las culturas, las clases sociales... Poco tiene que ver la familia romana, con la familia patriarcal, o con la familia monogámica. Pues bien, con la infancia pasa lo mismo. A mí me suelen decir, pero Julia, «niños los ha habido siempre». Y yo suelo contestar, bueno, siempre ha habido unos seres que son de estatura más bajita que los adultos, que por lo general tienden a ser más revoltosos, aunque en la época a que nos referimos los tenían bien enfajaditos durante un cierto tiempo — como muestran algunas pinturas-, así que no podían moverse, pero niños, tal como los concebimos hoy no los ha habido siempre, pues el sentimiento de infancia es un sentimiento moderno, como mostró Philippe Ariès. 
¿Cómo se formó ese campo de la infancia? ¿Qué agentes tuvieron más peso en su constitución?

A partir de la segunda mitad del siglo XVI se configuran nuevos modos de educación que ponen de manifiesto la intensa preocupación de los reformadores y humanistas por el gobierno de la tierna edad. Los programas de enseñanza que diseñaron y desarrollaron constituyeron un dispositivo fundamental para definir el nuevo estadio temporal que hoy denominamos infancia, separado de los adultos y dotado de un estatuto de minoría.

Todavía en el Renacimiento las edades de la vida eran conceptos que suponían la existencia de una unidad fundamental entre los fenómenos naturales, cósmicos, y sobrenaturales. El movimiento que describían los planetas en sus órbitas celestes, el ciclo de las estaciones, las fases de la luna y el ciclo de la vida humana se regían por una misma lógica. El microcosmos era un reflejo del macrocosmos y el hombre se relacionaba con todos los seres del universo a través de lazos profundos y misteriosos. Las edades de la vida no estaban por lo tanto ligadas al desarrollo biológico.

Dominaban dos sistemas en el establecimiento de las edades de la vida, uno que las definía a partir de periodos de 7 años, que tuvo su efecto casi hasta nuestros días (a los 7 años se hacía la primera comunión, a los 21 se era mayor de edad). Y otro en periodos de 20 años: infancia, juventud, madurez, senectud, nombres que seguimos utilizando, pero que no significaban lo mismo. Pero, ¿por qué se establecían esas cuatro edades? Pues porque estaban relacionadas con las cuatro estaciones, con las cuatro fases de la luna, etc., es decir, la vida humana formaba parte del orden del cosmos. Sin embargo, hoy, cuando hablamos de infancia, nos referimos a una edad biológica concreta, ligada a nuestro desarrollo individual.

Para contestar a cómo se formó el campo de la infancia, se podría decir que las definiciones sociales de infancia están ligadas a las condiciones objetivas de vida, a los desequilibrios de poder existentes en cada época entre los distintos grupos sociales, y también a las reglas sistemáticas, a las «pedagogías» por medio de las cuales los adultos trataron y tratan de educar a «los niños». En el capítulo II de Arqueología de la escuela se ilustra mediante algunos cuadros cómo cambió la percepción social de la infancia. 
Se podría decir que históricamente existieron tres momentos importantes: el siglo XVI, el siglo XVIII, y el siglo XX.

En el siglo XVI los humanistas produjeron nuevas teorías y prácticas educativas, que fueron reinterpretadas por los jesuitas, y la Ratio Studiorum.

En el siglo XVIII serán los ilustrados, y especialmente Juan Jacobo Rousseau, los que vuelvan a redefinir el campo y aboguen por la llamada educación natural.

Y, por último, en el siglo XX, cuando se puso en marcha la escolaridad obligatoria, el campo es remodelado de nuevo no solo por la pedagogía, sino también por nuevos saberes como el psicoanálisis, la psicología infantil, la puericultura...

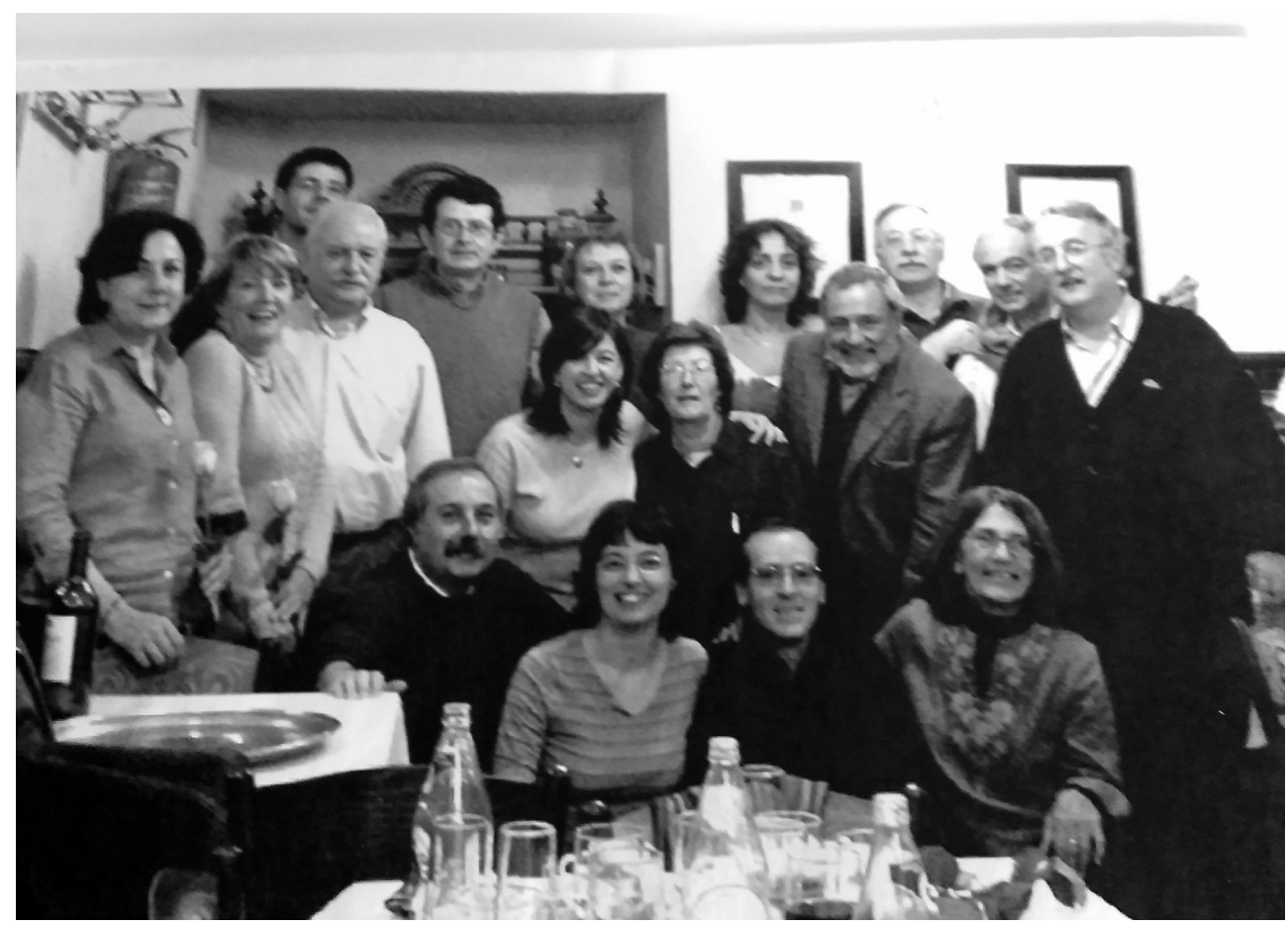

Con un grupo de amigos de la tertulia «los jueves alternos» del Ateneo de Madrid, 2008. 
En esos distintos momentos a la infancia se le confieren cualidades diferentes...

Bueno, se puede afirmar esto un tanto esquemáticamente, porque en el siglo XVI coexisten distintas definiciones, pero la que va a generalizarse es aquella que considera que la naturaleza infantil es maleable, dúctil, flexible, que tiene memoria y es capaz de imitación. Todas ellas cualidades que la hacen apropiada para ser educada. Eso sí, también se considera que los muchachos son aviesos e inclinados al mal debido al pecado original, por lo que hay que tutelarlos, y evitarles los peligros del mundo. Los jesuitas son partidarios, por lo tanto, de una nueva forma de educar a los niños que implica separarlos de los adultos para encerrarlos en los colegios. Estamos hablando de la infancia masculina, que es la que va a esos colegios.

Hasta entonces los niños y las niñas se socializaban y se educaban cada uno en su grupo social, aprendiendo oficios; desde los nobles y las nobles que aprendían los oficios de su propia clase social -algunos infantes acompañaban a los caballeros al campo de batalla- hasta los médicos, los herreros, o los carpinteros, etc.

Los jesuitas son los que van a inaugurar este nuevo modo de educación en un momento en que para el orden social, tanto para la monarquía como para la iglesia, es muy importante formar buenos súbditos y buenos cristianos.

Como decías, los ilustrados rompen con esa definición, le atribuyen nuevas cualidades y son partidarios de una forma distinta de educarlos.

Sí, fueron los ilustrados, o en todo caso se le atribuye a Rousseau, que fue quien más influjo tuvo posteriormente, la idea de que niño es diferente de los adultos, que tiene sus formas de pensar, de sentir, y de actuar propias, y quien le confiere una nueva cualidad, la de ser inocente. Pero, ¿de dónde les viene esa nueva cualidad de la inocencia? Se debe a que los niños llevan unos cuantos siglos separados del mundo de los adultos, mediante un sistema de educación que los ha tutelado, infantilizado, podemos decir, de algún modo. Pero además Rousseau, que estudió con los jesuitas, inauguró un sistema de educación opuesto al de ellos, que denominó educación natural. 
Pero, ¿esa llamada educación natural, que propone Rousseau, responde a las necesidades naturales del niño?

Las pretendidas necesidades naturales del niño quien las define en realidad es Rousseau, quien, sobre todo con su tratado el Emilio, ha tenido mucho peso en la Escuela Nueva y en otras formas de educación, denominadas alternativas. Su visión de la educación conecta sin duda con los intereses de una parte de la burguesía ilustrada que está accediendo al poder. Rompe con el encierro jesuítico, con la disciplina visible, con una educación libresca, y propone que hasta los 12 años, durante la denominada edad de la naturaleza, Emilio reciba una educación destinada a desarrollar su cuerpo, sus sentidos, su sensibilidad. El cultivo del ingenio, de la inteligencia, durante esos años, partirá por tanto de lo sensible, no de los libros. La educación intelectual y moral queda reservada a edades posteriores. Rousseau propone una educación individualista e idealista: un preceptor por alumno. La educación sigue privilegiando a los varones, ya que para Sofía, la compañera de Emilio, no reivindica una educación similar: basta con que se prepare para ser una buena esposa y buena madre.

La educación que propone Rousseau implica una forma de control menos visible.

Sí, se pasa de una pedagogía, la de los jesuitas, que supone un control visible (organización jerárquica de la clase, distribución del espacio, de los programas de enseñanza, del tiempo, de las actividades, exámenes, premios y castigos...) a otro tipo de control que, aunque menos visible, es aún más riguroso. Algunos textos del Emilio son muy reveladores en este sentido:

Tratad a vuestro alumno según su edad. Antes que nada colocadlo en su lugar y mantenedlo de tal forma que nunca intente salir de él [...]. No le mandéis jamás nada, sea lo que sea, absolutamente nada. No le dejéis siquiera imaginar que pretendéis tener autoridad sobre él; que sepa solamente que él es débil y vosotros sois fuertes; que por su estado y el vuestro se encuentra necesariamente a vuestra disposición; que lo sepa, que lo aprenda, que lo sienta. Que sienta en buena hora sobre su altiva cabeza el yugo que la naturaleza impone al hombre, el pesado yugo de la necesidad [...].2

\footnotetext{
2 Jean-Jacques Rousseau, Émile ou De l'éducation (Paris: Garnier-Flammarion, 1966), 109. Traducción Julia Varela. Citado en Julia Varela y Fernando Álvarez-Uría, Arqueología de la escuela (Madrid, Ediciones de La Piqueta, 1991), 80.
} 
Como se puede observar el preceptor aquí todavía es más todopoderoso que el maestro jesuita. ¿Dónde quedan entonces las necesidades naturales del niño? Émile Durkheim señalaba que toda pedagogía, toda educación, sea escolar o no, supone una imposición sobre las nuevas generaciones.

Emilio es un libro que está plagado de las triquiñuelas de las que se sirve el preceptor para que su discípulo quiera hacer las cosas que debe hacer sin que el preceptor se las ordene. Pero para eso tiene que controlar de forma minuciosa el medio, todo lo que lo rodea, personas, animales y cosas.

\section{En la llamada Escuela Nueva se siente el influjo de Rousseau...}

Sí, y así ya entramos en la tercera etapa de redefinición de la infancia, en el siglo XX. Sin duda, al menos los pedagogos de la Escuela Nueva adoptan la idea de que los niños tienen sus específicas formas de pensar y de sentir. Se suelen citar sobre todo a dos de sus más conocidos representantes: Ovide Decroly y María Montessori.

María Montessori resulta paradigmática en este sentido, y no solo por la preparación del ambiente, sino también porque incluso adapta las mesas, las sillas, y los materiales concretos de enseñanza que diseña a escala de los niños: mesitas pequeñas, juguetes y demás.

Estas pedagogías empezaron siendo aplicadas por Decroly y Montessori a niños que tenían problemas, de modo que lo que llamamos ahora pedagogías alternativas, que generaron numerosas experiencias que se desarrollaron en distintos países europeos a lo largo del siglo XX, hunden sus raíces en la pedagogía rousseauniana, y en las pedagogías «terapéuticas». No me puedo detener ahora en estas experiencias que van desde la llamada educación en libertad de Summerhill hasta los colegios promovidos por la Institución Libre de Enseñanza.

En esta tercera etapa de redefinición de la infancia se podría decir que ya no es solo la educación lo que es natural, sino que lo que se define es la naturaleza misma del propio niño. La psicología evolutiva marca unos periodos de desarrollo que se consideran universales pues supuestamente provienen del interior del niño, de su propio ser natural. 
El influjo de Rousseau llega incluso hasta la psicología de Jean Piaget

Sí, no sé si Piaget fue muy consciente de ello, pero los estadios del desarrollo cognoscitivo del niño postulados por Piaget (etapa sensorio-motora, etapa pre-operacional, etapa de las operaciones concretas y etapa de las operaciones formales) reenvían sin duda a las etapas que establece Rousseau en el Emilio.

En todo caso lo que resulta interesante comprobar es que cuando los adultos definen las necesidades naturales del niño están definiendo a la vez cómo debe ser su educación. Afortunadamente no sabemos lo que son los niños y las niñas, y esta ignorancia nos permite en parte relativizar códigos psicopedagógicos que se presentan como incuestionables. En todo caso a mí me interesa mostrar, a partir de un análisis genealógico, que en la actualidad siguen existiendo distintos modos de educación, y distintas percepciones sociales de la infancia.

Bueno, como supongo que luego volveremos a cuestiones relacionadas con la educación me gustaría que pasásemos ahora a hablar de tu libro Nacimiento de la mujer burguesa que Ediciones Morata acaba de reeditar en una nueva versión corregida y aumentada. ¿Qué pretendes mostrar o demostrar con este libro?

Para decirlo brevemente, con ese libro pretendo explicarme a mí misma y a los demás cómo y por qué surgió esa figura ideal de la mujer identificada casi exclusivamente con ser buena madre, buena esposa y buena cuidadora del hogar. Ese ideal de la mujer cristiana, ese supuesto eterno femenino, empezó a gestarse a finales de la Edad Media, y en buena medida se materializó y generalizó en el siglo XIX, cuando la burguesía accedió al poder político, y se convirtió en la nueva clase dominante.

En ese libro no me desvinculé de la educación pues además de mostrar cómo las mujeres fueron expulsadas de las universidades, he intentado objetivar algunos programas que determinados humanistas pusieron en marcha para la educación de las mujeres. 


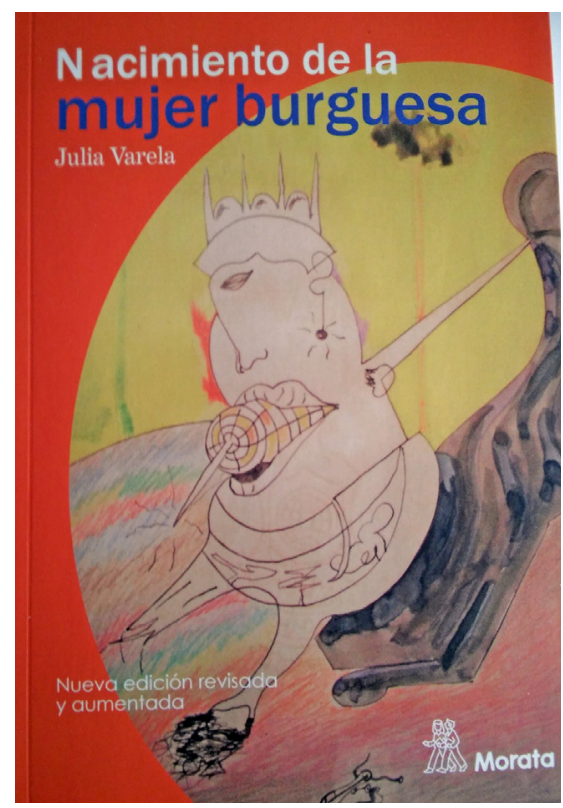

Cubierta del libro Nacimiento de la mujer burguesa.

En Nacimiento de la mujer burguesa también acuñaste nuevos conceptos para analizar la interacción de los distintos procesos que fueron necesarios para que se pusiese en marcha ese ideal de feminidad.

Me serví del concepto de dispositivo de feminización, que tiene como referencia el dispositivo de sexualidad de Foucault. Ese concepto me pareció útil para poner en interacción distintos procesos que se desarrollaron desde finales de la Edad Media: cambios importantes en las leyes de transmisión de la herencia, cambios que introducen los canonistas en la legislación para imponer el matrimonio monogámico indisoluble, cambios en el mundo del trabajo, pues cuando empiezan las ciudades a tener un auge fuerte, surgen nuevos oficios en esas ciudades, y nuevas formas de organización de las relaciones laborales: los gremios. El libro de Sombart, Lujo y capitalismo, es importante en este sentido, pues además de referirse a otros aspectos interesantes en relación con la redefinición social de los sexos — la expresión es suya- que está teniendo lugar en esa época, confiere una gran importancia a las modas establecidas por las mujeres de la nobleza cortesana para el despegue de la industria textil capitalista. 
Uno de los capitulos importantes del libro, al que te referiste, trata de cómo las mujeres van a ser expulsadas de las universidades cristianoescolásticas, es decir, de las universidades que ponen en marcha los dominicos y los franciscanos a finales de la Edad Media.

Sí, hasta entonces, las mujeres no solo ejercían muchos de los oficios que ejercían los varones, sino que también asistían a los Estudios Generales, importantes centros de estudios que antecedieron a las universidades cristiano escolásticas, y que coexistieron con ellas durante un tiempo.

Algunos libros me sirvieron de mucha ayuda, por ejemplo un libro de Luis García Ballester, creo se titula Historia de la medicina social en España, que a través de textos de época mostraba cómo mujeres, tanto judías, como moras y cristianas, de la península, iban a los Estudios de medicina, y asistían a los miembros de las Cortes de Aragón, de Castilla..., es decir, que ejercían el oficio de físicas —así se denominaba en la época a los médicos-, y entre ellas cita a algunas terapeutas muy famosas. También encontré estudios que mostraban cómo en la Escuela de Traductores de Toledo, había mujeres traductoras. Pero, a partir del momento en el que se fundaron las universidades cristiano-escolásticas los eclesiásticos excluyeron a las mujeres de esos estudios. En definitiva, únicamente podían ser varones los que estudiasen medicina, leyes, artes o teología. Durante un tiempo ambos centros de estudios coexistieron, pero cuando triunfó la Contrarreforma católica los Estudios Generales fueron suprimidos.

Esto conecta con lo que decías que te interesaba especialmente, es decir, la expulsión de las mujeres del espacio público.

En Nacimiento de la mujer burguesa dediqué un capítulo a los programas de educación que establecieron los humanistas para las mujeres de ciertos grupos sociales. Retorno una vez más a esa época de los siglos XV y XVI porque fue un periodo muy importante no solo para el gobierno político, sino también para la formación del matrimonio monogámico indisoluble y para la institución de la mujer cristiana.

Desde finales de la Edad Media se estaba debatiendo sobre cuál era la naturaleza de las mujeres, lo que se conoce como la querella de las mujeres. Había unas disputas enormes sobre esta cuestión, ya que de la 
definición de la naturaleza de las mujeres dependía la educación y las funciones que se les iban a atribuir.

Cuando analizas los modos de educación, pero también cuando buscas desvelar cómo se produjo el modelo de mujer cristiana, te refieres siempre a los cambios en la estructura y en la dinámica social. Este es un tema que vuelve a salir constantemente en tus análisis.

Me interesan los cambios sociales que se produjeron a finales de la Edad Media, los cambios que tuvieron lugar en el momento en el que se produjo la Ilustración, así como los producidos por la revolución industrial que conoció su despegue en el siglo XIX y que tan bien describe Friedrich Engels en La situación de la clase obrera en Inglaterra. Pero, en realidad, intento seguir la trama de todos esos cambios para tratar de proyectar un poco de luz en los procesos sociales que están teniendo lugar en la actualidad... Me parece que ése es en esencia el oficio de sociólogo: diagnosticar el presente, teniendo siempre en cuenta que el presente se enraíza en la historia social e intelectual.

La historia no es acumulativa, ni se rige por la ley del progreso. Por lo que tú señalas, algunos de los programas de educación que desarrollaron humanistas italianos para las mujeres eran relativamente innovadores...

Claro, por ejemplo, creo que era Leonardo Bruni quien afirmaba que las mujeres no tenían que preocuparse con las sutilezas de las argumentaciones, ya que no estaban destinadas al foro; por lo tanto, no les era necesario el bien hablar, el estudio de la retórica. Tampoco debían formarse en aprendizajes propios de la guerra, porque tampoco convenía que fuesen al frente de sus ejércitos. ¿Qué quiere decirnos todo esto? Que había mujeres que iban al frente de sus ejércitos, y que había mujeres que sabían hablar muy bien, y que eran grandes oradoras. Conocidas son toda una serie de mujeres humanistas como Cristina de Pizán, Isotta Nogarola, Laura Cereta, Louise Labé, etc., que tuvieron a varones humanistas como amigos, y como preceptores.

Además de Leonardo Bruni, el Aretino, quien en su tratado De Studiis et litteris, que dedica a una mujer, Battista Malatesta de Montefeltro, se refiere a la educación de las mujeres, hubo muchos otros humanistas italianos que, desde el siglo XIV, escribieron sobre la educación de las mujeres, sobre todo nobles, y fueron sus amigos y preceptores. Por citar 
algunos están Vittorino da Feltre, Pier Paolo Vergerio, Guarino de Verona, Bartolomeo Facio, Francesco Barbaro, Lorenzo Valla, Gregorio Correr, etc.

Vittorino da Feltre abrió La casa giocosa en la corte del Duque de Mantua, Jean Francesco I Gonzaga, que se casó con Isabella d’Este, a quien dedicó Alberti su libro sobre la pintura. La casa giocosa estaba dedicada a educar los hijos de los duques de Mantua, y llegó a ser una de las escuelas humanistas más famosas de su tiempo, a la que otros nobles mandaron también a sus hijos.

Guarino, que escribió De ordine docendi et studendi, tuvo una escuela de lengua griega en la corte de Verona, pero la más famosa fue la que estableció en Ferrara. Martino Rizzoni, uno de sus discípulos, educó a Isotta Nogarola. Muchos de estos humanistas, al igual que luego Vives y Erasmo, no sólo fueron consejeros de príncipes, sino que vivieron en la corte de los nobles y educaron a sus hijos y a sus hijas. Rompieron con la escolástica, y crearon los Estudios de humanidades, pues tenían una concepción distinta de lo que debía de ser la educación para formar el nuevo ciudadano, un hombre ilustrado y de buenas maneras.

Se dice que Baltasar Castiglione en su libro El Cortesano fue quizás quien afirmó una mayor igualdad entre hombres y mujeres.

Sí, además ese tratado de buenas maneras, marcó el ceremonial de las Cortes italianas y de toda Europa. El Cortesano fue un libro que tuvo un éxito impresionante, se tradujo rápidamente a numerosas lenguas. Al castellano lo tradujo Boscán en 1534, y parece que lo leyeron detenidamente escritores tan importantes como Rabelais y Montaigne, pero también Shakespeare y Cervantes. Con él cobra un especial relieve la figura de la dama de la Corte, a cuya formación se dedica una parte del libro. Castiglione pasó un tiempo en la Corte del conde de Urbino, en donde especialmente Elisabetta Gonzaga, pero también su cuñada Emilia Pía, jugaron un importante papel y de hecho conducen la conversación, el diálogo del libro.

En el tercer libro del Cortesano Castiglione se detiene en las cualidades que debe tener la noble dama, y su formación, y afirmaba que todas las mujeres tienen derecho a pensar, que todas tienen que recibir por lo tanto una educación clásica, hablar bien, saber no solo de letras 
clásicas, sino también música y pintura. Y poseer cualidades que son comunes con el cortesano, tener gracia en sus acciones, ser prudente, huir de la afectación, no ser envidiosa, ni soberbia, ni maldiciente... Pero la cortesana debe de ser más delicada, más dulce, cuidar más de su honra, ser honesta, saber gobernar bien la casa, y educar a sus hijos... Es decir que esa igualdad era relativa.

Tanto la nobleza como la burguesía tenían entonces sus propios estilos de vida y desempeñaban distintas funciones. Castiglione no se refiere explícitamente a las mujeres de las clases populares, pero dice que había ciertas cosas que no debían de hacer las mujeres, que era tocar ciertos instrumentos musicales que les deformasen la expresión, como la trompeta o el tambor, y que no debían de bailar ciertos bailes o hacer ciertos ejercicios que exigían movimientos violentos. En todo caso, la importancia de la apariencia, el cuidado del cuerpo, la hexis corporal establecía una distancia enorme entre las mujeres de la nobleza, y las de la burguesía, y las mujeres de las clases populares.

Se podría decir que todos estos humanistas fueron «más suaves» que otros, como Vives y Erasmo, en cuya obra se deja sentir ya con fuerza el peso de la Contrarreforma.

Sí. Vives y Erasmo estaban muy interesados en la institución de la mujer cristiana. Fueron ellos los principales portavoces de esos nuevos grupos medios que estaban emergiendo en las ciudades, que empezaban a tener más poder, como los banqueros, los comerciantes, los profesionales que ejercían las profesiones liberales, que se habían formado en las universidades cristiano-escolásticas. Vives y Erasmo fueron muy críticos con el clericalismo, la barbarie escolástica y los frailes, pero sin duda el peso de la Contrarreforma se percibe en sus escritos, especialmente en los que se refieren a este nuevo arquetipo de mujer.

Vives escribió dos libros muy importantes, Institución de la mujer cristiana y El oficio del marido. Pero también jugará un papel notable en este sentido Fray Luis de León, con su libro La perfecta casada. Todos estos humanistas, y también los reformadores, tanto católicos, como protestantes, van a definir ese campo en el que surge el nacimiento de la mujer burguesa. Los programas que desarrollaron para su formación y modo de vida son muy explícitos, muy rigurosos. Detallan lo qué tiene 
que hacer, cómo tiene que comportarse, cuáles son sus funciones, en fin, cuál es su naturaleza.

Vives decía que para la mujer la casa hace las veces de toda la República.

Y eso nos lleva al proceso de domesticación que van a sufrir las mujeres, en el sentido estricto, pues domus, es casa en latín. La mujer debe ser la reina del hogar: ocuparse del cuidado de la casa, del marido y de los hijos. Y ese gobierno de la casa poco tiene que ver con el que tiene lugar con el advenimiento de la familia conyugal, ya que entonces eran familias extensas de las que formaban parte de alguna manera también las criadas y criados.

Estos reformadores le dieron al matrimonio monogámico cristiano un empujón, porque plantearon que la mujer tenía que decir que quería casarse, que asentir en el momento de la ceremonia - frente a los matrimonios «arreglados» por las familias-, pero limitaron sus funciones al dominio de la casa. El ámbito público, el político, el ámbito de los saberes y los negocios, las funciones públicas quedaban vedadas para las mujeres, con la excepción de las mujeres públicas, las prostitutas.

Un texto de Vives quizás puede servir para que se entienda bien lo que estoy diciendo:

$\mathrm{Al}$ hombre muchas cosas le son necesarias, la prudencia, el bien hablar, la ciencia política, la memoria, el talento, el arte de vivir, la justicia, la liberalidad, la magnanimidad, pero en la mujer nadie busca la elocuencia, ni el talento, ni la prudencia, ni el arte de vivir, ni la administración de la justicia. Nadie reclama de ella sino la castidad. ${ }^{3}$

Este texto refleja bien la importancia que con las nuevas leyes del linaje, con las nuevas leyes de transmisión de la herencia, estaba cobrando el hecho de que la mujer únicamente debía tener hijos de su marido legítimo. Los reyes tenían sus amantes. Juan de Austria fue hijo reconocido de Carlos V... Norbert Elias en La sociedad cortesana no solo hace

\footnotetext{
3 Juan Luis Vives, Instrucción de la mujer cristiana, en Obras Completas (Madrid: Aguilar, 1947), t. I, 1010. Obra dedicada a Catalina de España, reina de Inglaterra; citada en Julia Varela, Modos de educación en la España de la Contrarreforma (Madrid, Ediciones de La Piqueta, 1983), 180.
} 
referencia a las famosas amantes de Luis XIV, sino que señala además que las reinas también tenían amantes, pero esto ha sido más censurado por los historiadores de la burguesía. A partir de la Contrarreforma los bastardos dejaron de figurar en las listas de sucesión de los reyes. Hasta entonces el amor y el matrimonio no estaban unidos en las relaciones que mantenían los nobles. Habrá que esperar al triunfo de la burguesía $\mathrm{y}$ al post-romanticismo para que se vaya imponiendo de forma bastante generalizada el amor conyugal...

Creo recordar que en Nacimiento de la mujer burguesa no solo contrapones la figura de la mujer cristiana a la dama cortesana - de hecho, cortesana pronto adquirirá el sentido de prostituta-, sino también a las mujeres de las clases populares.

Sí, en este sentido puede servir una vez más un texto de Juan de Pineda que dice así: «Frente a la mujer bestia, puerca, raposa y perra ladradora, frente a la mujer inmunda, se alza la mujer virgen, la mujer fiel —paloma—, la mujer trabajadora —abeja—, la mujer prudente — serpiente-». ${ }^{4}$ Los moralistas católicos contrarreformistas del siglo XVI fueron todavía más lejos que los humanistas al contraponer la imagen de «la mujer buena, que pone su honra en ser muy fiel y honesta, muy compasiva y piadosa, muy verdadera cristiana y virtuosa [a la de] la mala mujer [que es] infiel, deshonesta, tirana y cruel, y carece de verdad y virtud». 5

Estos textos, y otros de la época que recojo en mi libro, son verdaderamente estremecedores, pues prácticamente todas las mujeres de las clases populares pasaron a formar parte de las indexadas como malas mujeres: las vagabundas, las alcahuetas, las celestinas, las brujas, las hechiceras...

Para combatir a estas malas mujeres se crearon toda una serie de instituciones de represión y castigo con el fin de reformarlas. Las galeras y el fuego inquisitorial se ocuparán de aquellas que no aceptaban las

\footnotetext{
4 Juan de Pineda, Diálogos familiares de la Agricultura Cristiana (1521-1599) (Madrid, BAE, 196364), t. IV. Citada en Julia Varela, Nacimiento de la mujer burguesa (Madrid, Morata, 2019), 229.

5 Fray J. de la Cerda, Libro intitulado vida política de todos los estados de mujeres (Alcalá de Henares, 1599), 585. Citada en Julia Varela, Nacimiento de la mujer burguesa (Madrid, Morata, 2019), $229-230$.
} 
nuevas normas que tanto la iglesia como los monarcas y las autoridades municipales querían imponer.

En fin, el ideal de la mujer cristiana surgió, no sólo en contraposición con las mujeres populares y con las mujeres de la nobleza, sino también con el ideal del varón cristiano. En este sentido resulta esclarecedor comparar El oficio de marido con la Institución de la mujer cristina, de Vives.

Si te parece retomamos otra vez la cuestión de la educación y su impacto en la formación de identidades y formas de subjetivación específicas.

Los humanistas, contribuyeron especialmente a la formación de la identidad social de las élites, tanto de la nobleza cortesana, como de una parte de lo que podríamos llamar alta burguesía y de la burguesía. Como ya señalé abrieron escuelas en las cortes principescas y también los Estudios de humanidades a los que asistían los hijos de la burguesía urbana.

En Modos de educación en la España de la Contrarreforma, y en Arqueología de la escuela me ha interesado especialmente resaltar que fueron los jesuitas quienes lograron un nuevo estatuto de nobleza, la nobleza de las letras, para los hijos de aquellos grupos de los que eran portavoces a partir del siglo XVI, lo que les permitió ocupar un espacio intermedio en la organización social. Consiguieron así a la larga romper con una estructura social cuya cúspide estaba ocupada por la nobleza cortesana y por la nobleza ligada al linaje. Y al mismo tiempo sentaron las bases para un proceso de individualización basado en el mérito individual. Michel Foucault en Vigilar y Castigar muestra cómo la enseñanza de los jesuitas, y de otras órdenes religiosas, va a jugar un papel importantísimo en la formación de ese nuevo individuo moderno, a través de ese proceso de individualización en el que desempeñaron un papel muy importante los exámenes, aplicados de forma sistemática. Los exámenes no solo servían para jerarquizar y normalizar, permitían dividir a los estudiantes, y conferirles una naturaleza individualizada: inteligentes, tontos, trabajadores, vagos, honestos, deshonestos, silenciosos, habladores...

El proceso de individualización y el sistema meritocrático lleva a pensar a muchos que tanto los éxitos como los fracasos cosechados 
escolarmente se deben exclusivamente a su propio mérito individual. Pierden así la perspectiva de que son sujetos sociales, y que el supuesto mérito individual es el resultado en gran medida de los capitales heredados, de las relaciones sociales que mantienen en la familia, con los amigos, con los profesores...

El modelo de análisis del que me he servido en estas investigaciones de sociología histórica de la educación creo que se diferencia tanto del marxismo clásico de la reproducción como del funcionalismo parsoniano, ya que en estos estudios se defiende la autonomía relativa del campo de la educación y se analizan las funciones sociales de los distintos modos de educación. La 'tesis' de fondo sería que el sistema escolar, que suele presentarse como único, es diverso en su génesis y en su funcionamiento, y que desempeña distintas funciones no solo en cada época histórica, sino también en función de los grupos sociales a los que va dirigido.

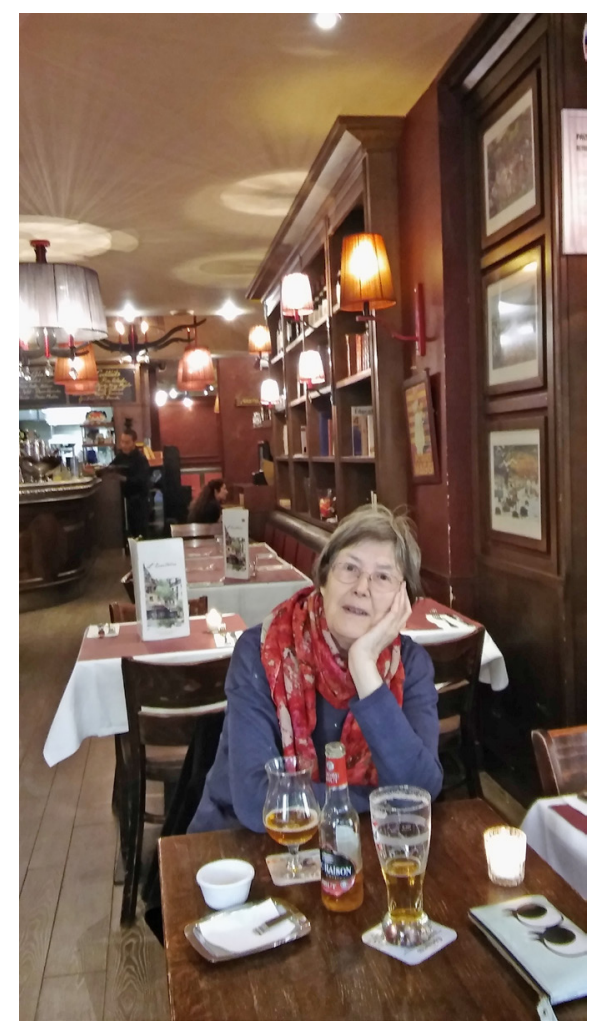

Julia Varela en L'Écritoire, Plaza de la Sorbona, París 2017. 
Cambiar el sistema educativo para reducir las desigualdades sociales parece hoy más difícil que en los años ochenta. Me gustaría saber qué piensas que se podría hacer para mejorar la escuela pública, ante la ofensiva neoliberal.

Responder a esta pregunta en profundidad exigiría tiempo. Voy intentar esbozar algunas cuestiones, siguiendo el hilo de lo que veníamos hablando. El sistema escolar, tal como lo ponen en marcha los jesuitas, se instituyó en un momento de absolutismo político. Por eso para romper con su lógica de funcionamiento y hacer que opere de un modo más democrático, es decir, para transformar la maquinaria escolar, hay que cambiar sus piezas constitutivas: la institución de la infancia, la formación de un cuerpo especializado dedicado a enseñar (los maestros), la selección de ciertos saberes (su pedagogización), el espacio cerrado (los colegios), y la destrucción de otras formas de socialización...

Es preciso por tanto analizar los efectos que producen determinadas concepciones de la infancia, según las cuales los niños y niñas son ignorantes - o seres inocentes, como decía Rousseau-, o perversos polimorfos... Tener en cuenta que los niños no son una tabula rasa, como se decía, sino que tienen determinados saberes que conviene no despreciar. Hay que enfrentarse también a cuál debe de ser la formación de los profesores que variará según se piense que deben ser animadores culturales o autoridades de conocimiento, o ambas cosas a la vez. Respecto al espacio cerrado preguntarse cómo se puede abrir al entorno, a las familias, a otros profesionales... Por lo que se refiere a los saberes que hay que transmitir, parece conveniente que no sean saberes a-históricos, censurados, alejados del mundo, sino, por el contrario, saberes que den cuenta de lo que está pasando, que de este modo conectarán más fácilmente con los intereses de los estudiantes. Y por último, frente al desprecio de los saberes de las clases populares y de otras culturas, y esto cada vez más debido a la inmigración, plantearse cómo pueden formar parte del currículo escolar.

Se puede percibir todavía hoy cómo los distintos agentes sociales, los grupos políticos, la iglesia, etc., luchan por dominar el espacio de la educación escolar. Y también que siguen existiendo distintos modos de educación, distintas percepciones de lo que es la infancia, y por lo tanto, distintos debates sobre la forma en que hay que educarla que reenvían a 
las luchas que existen entre los distintos grupos sociales, a relaciones de fuerza que atraviesan también a las instituciones escolares y el campo intelectual.

Me cuesta cerrar tan rápido esta importante pregunta; podría añadir que he escrito algunos textos y participado en algunos debates que se refieren a ciertos aspectos de la misma. Recuerdo ahora, por ejemplo, «Clases sociales, pedagogías y reforma educativa», que está disponible online, y «Balance de una frustración», a raíz de la publicación de mi libro Reformas educativas a debate.

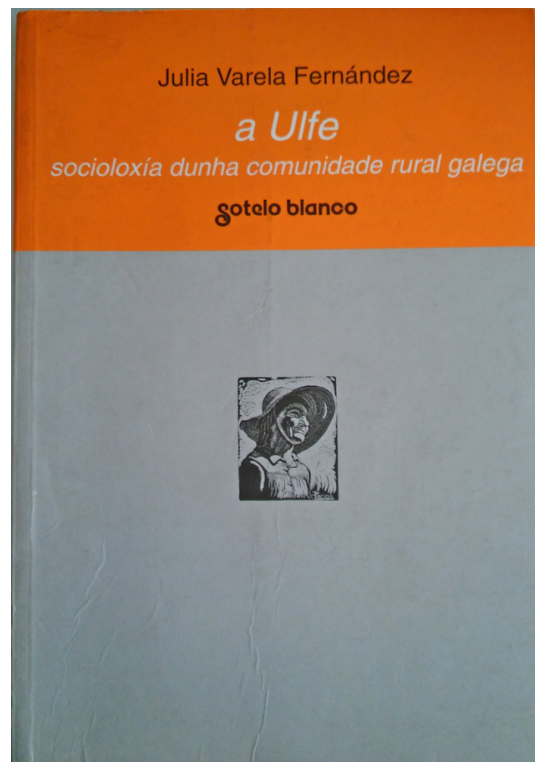

Cubierta de su libro A Ulfe. Socioloxía dunha comunidade rural galega.

Julia, como no solo has escrito libros sobre educación, sino sobre otras cuestiones, me interesaría prolongar un poco más esta entrevista y preguntarte por otros trabajos posteriores, pues en un determinado momento la sociología histórica ya no está tan presente.

Efectivamente, he realizado con Fernando Álvarez-Uría algunos trabajos, como Sociología, capitalismo y democracia, que sigue siendo un estudio de sociología histórica, y en buena medida también Sociología de las instituciones. Pero, en efecto, a partir de A Ulfe, me dediqué más a otras cuestiones, reflejadas en obras como Mujeres con voz propia, 
Memorias para hacer camino, Mercedes Valcarce: maestra de maestros..., y aunque Pierre Bourdieu dice que los estudios antropológicos y los sociológicos son similares, suponen un cambio de perspectiva.

A Ulfe. Socioloxía dunha comunidade rural galega, marcó un antes y un después en mi forma de investigar. Fue un trabajo que me sacó de los archivos y me conectó de nuevo con mi gente del mundo rural. Reforcé mis raíces y disfruté mucho entrevistando a mujeres y hombres de distintas generaciones, algo que, por lo que dicen, se nota en el libro. Me hice más consciente de la riqueza de la civilización rural que estaba desapareciendo, y que yo intentaba que permaneciese viva por más tiempo, aunque fuese a través de un documento escrito. Es un libro al que tengo una especial estima.

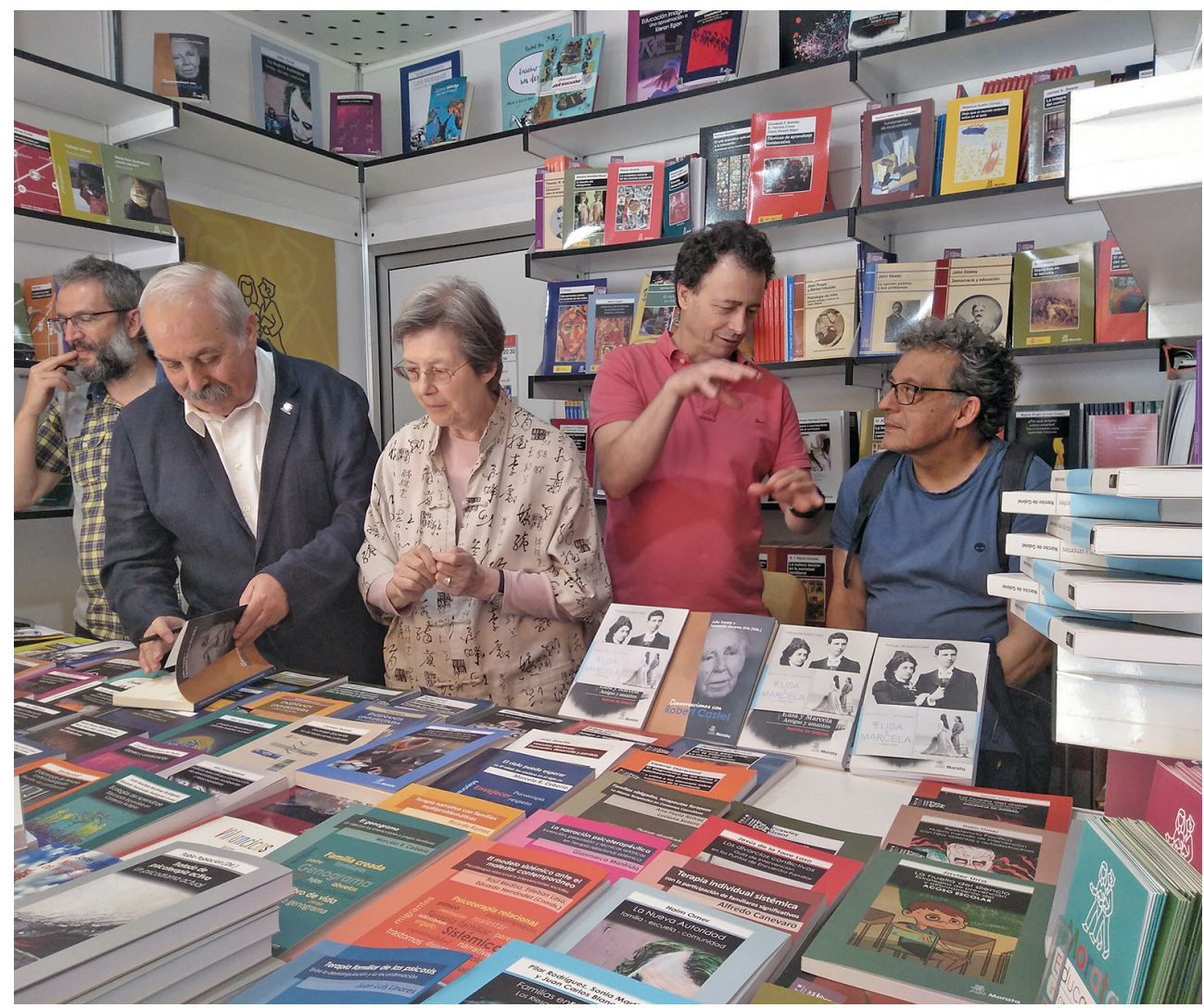

Feria del Libro de Madrid, 2019. De izquierda a derecha: Ernesto Pesquera, Fernando ÁlvarezUría, Julia Varela, Paulo Cosín y Narciso de Gabriel. 
¿Qué vínculos existen entre esos trabajos que acabas de citar y los anteriores?

En primer lugar, la historia siempre sigue estando en el trasfondo de todos ellos; son trabajos que pretenden revitalizar la memoria, que no se pierdan en el olvido luchas visibles, y la mayor parte de las veces invisibilizadas, así como los valiosos saberes de las mujeres. Por otra parte, la educación sigue siendo en todos ellos una dimensión central para definir quiénes son esas mujeres que nos hablan de sus vidas, y que nos proporcionan materiales preciosos para la reflexión y la acción. ${ }^{6}$

\section{SELECCIÓN DE OBRAS DE JULIA VARELA FERNÁNDEZ}

\section{Libros}

- Modos de educación en la España de la Contrarreforma. Madrid: La Piqueta, 1983.

- El aprendiz de maestro: un análisis sociológico de los estudiantes de magisterio del distrito universitario de Madrid. Madrid: Ministerio de Educación y Ciencia, 1984 (con Félix Ortega Gutiérrez).

- Las redes de la psicología. Madrid: La Piqueta, 1986 (con Fernando Álvarez-Uría).

- Sujetos frágiles. Ensayos sociológicos de la desviación. México-Madrid: Fondo de Cultura Económica, 1989 (con Fernando Álvarez-Uría).

- Arqueología de la escuela. Madrid: La Piqueta, 1991 (con Fernando Álvarez-Uría).

- Nacimiento de la mujer burguesa: el cambiante desequilibrio entre los sexos. Madrid: La Piqueta, 1997 (nueva edición revisada y aumentada, Madrid: Morata, 2019).

\footnotetext{
${ }^{6}$ Algunas obras de los autores citados por Julia Varela en la entrevista: Erasmo, De la urbanidad en las maneras de los niños (Madrid: MEC, 1985) (ed. Julia Varela); Michel Foucault, Las palabras y las cosas. Una arqueología de las ciencias humanas (México: Siglo XXI, 1968); Michel Foucault, Vigilar y castigar. El nacimiento de la prisión (México: Siglo XXI, 2005); Émile Durkheim, Las formas elementales de la vida religiosa (Madrid: Alianza Editorial, 2003), La división del trabajo social (Madrid: Akal, 1987) e Historia de la educación y de las doctrinas pedagógicas (Madrid: La Piqueta, 1982 y Morata, 2019); Norbert Elias, El proceso de la civilización: investigaciones sociogenéticas y psicogenéticas (Madrid: F.C.E., 1987), La sociedad cortesana (México: F.C.E., 1982) y Mi trayectoria intelectual (Barcelona: Península, 1995); Basil Bernstein, «Clases y pedagogías: visibles e invisibles», en La enseñanza: su teoría y su práctica, coords. José Gimeno Sacristán y Ángel Pérez (Madrid: Akal, 1985), 54-72; Claude Grignon y Jean-Claude Passeron, Lo culto y lo popular (Madrid: La Piqueta, 1992); y Claude Grignon, "La escuela y las culturas populares», Archipiélago, Cuadernos de crítica de la cultura 6 (1991): 15-19.
} 
- La galaxia sociológica: Colegios invisibles y relaciones de poder en el proceso de institucionalización de la sociología en España. Madrid: La Piqueta, 2000 (con Fernando Álvarez-Uría).

- A Ulfe. Socioloxía dunha comunidade rural galega. Santiago de Compostela: Sotelo Blanco, 2004.

- Sociología, capitalismo y democracia. Génesis e institucionalización de la sociología en Occidente. Madrid: Endymion, 2004 (con Fernando Álvarez-Uría).

- Las reformas educativas a debate (1982-2006). Madrid: Morata, 2007.

- Materiales de sociología del arte. Madrid: Siglo XXI, 2008 (con Fernando Álvarez-Uría).

- Sociología de las instituciones. Bases sociales y culturales de la conducta. Madrid: Morata, 2009 (con Fernando Álvarez-Uría).

- Mujeres con voz propia. Carmen Baroja y Nessi, Zenobia Camprubí Aymar y María Teresa León Goyri. Madrid: Morata, 2011.

- Memorias para hacer camino. Relatos de vida de once mujeres españolas de la generación del 68. Madrid: Morata, 2016 (con Pilar Parra Contreras y Alejandra Val Cubero).

- Mercedes Valcarce Avello. Maestra de maestros. Madrid: Morata, 2018.

- Conversaciones con Robert Castel. Madrid: Morata, 2019 (con Fernando Álvarez-Uría).

- Mi pequeño París. Madrid: Morata, 2019.

Algunos artículos y colaboraciones en obras colectivas relacionadas con las temáticas tratadas en la entrevista.

- «Teoría y práctica en las instituciones escolares». En Marxismo y sociología de la educación, editado por Mariano Fernández Enguita, 143-154. Madrid: Akal, 1986.

- «Aproximación genealógica a la moderna percepción social de los niños». Revista de educación 281 (1986): 155-175.

- «Más allá de la 'reproducción': entrevista con Claude Grignon». Revista de educación 289 (1989): 275-285.

- «Clases sociales, pedagogías y reforma educativa». Revista de educación 292 (1990): 219-236.

- «El triunfo de las pedagogías psicológicas». Cuadernos de pedagogía 198 (1991): 56-59.

- «El cuerpo de la infancia. Elementos para una genealogía de la ortopedia pedagógica». En Sociedad, cultura y educación: homenaje a la memoria de Carlos Lerena Alesón, 229-248. Madrid: Universidad Complutense, 1991. 
- «Categorías espacio-temporales y socialización escolar: del individualismo al narcisismo». Revista de educación 298 (1992): 7-29 (con Fernando Álvarez-Uría).

- «El triunfo de las pedagogías psicológicas». En Las pedagogías psicológicas y el gobierno del yo en tiempos inciertos, 75-82. Madrid: Movimiento Cooperativo de Escuela Popular MCEP, 2000.

- «La escuela y sus funciones: de la reproducción social a la producción de identidades». En Los retos de la enseñanza pública, coordinado por José Gimeno Sacristán, 81-104. Madrid: Akal, 2001.

- «A crise da civilización labrega: sistema escolar e despoboación no mundo rural galego». Sarmiento: Anuario Galego de Historia da Educación 9 (2005): 51-60.

— «La voz de los archivos: mujeres, conflictos urbanos y sexualidad: entrevista con Judith R. Walkowitz». Minerva: Revista del Círculo de Bellas Artes 3 (2006): 112-115 (con Fernando Álvarez-Uría).

- «El declive de la civilización rural y sus efectos». En La fragilización de las relaciones sociales, editado por Jacques Donzelot [et al.], 131-156. Madrid: Círculo de Bellas Artes, 2007.

- «El poder de las imágenes. Las representaciones pictóricas de la Anunciación y el dispositivo de feminización». En Materiales de sociología del arte, editado por Julia Varela y Fernando Álvarez-Uría, 1-44. Madrid: Siglo XXI, 2008.

— «Balance de una frustración». Cuadernos de pedagogía 379 (2008): 80-83.

- «Goya's luminous tribute to women». Teknokultura 1 (2016): 321-325.

- «Una sociología al Servicio de la gente: conversaciones en torno a la obra de Robert Castel». Minerva: Revista del Círculo de Bellas Artes 26 (2016): 64-67 (con Fernando Álvarez-Uría y Juan Tabares).

\section{Nota sobre la autora}

Ana Iglesias Galdo (Ortigueira, 1962), inicia su trayectoria profesional trabajando durante 16 años como educadora en dos centros destinados a menores en conflicto social y dependientes de la Comunidad Autónoma Gallega. Premio extraordinario de doctorado por la Universidad de A Coruña (2006), ejerce como profesora en la Facultad de Ciencias de la Educación por encargo del Departamento de Pedagogía y Didáctica (área de Teoría e Historia de la Educación), ocupando la mayor parte de su docencia en el Grado de Educación social, y habiendo desempeñando además los cargos de vicedecana (2008-2012) y decana (2012-2016) en la misma Facultad. 
Bajo un compromiso crítico ante privilegios e injusticias, su docencia e investigación gira sobre la (in)justicia juvenil, el fracaso escolar y la relación entre feminismo y educación. Entre sus publicaciones destacan Educar e castigar. Unha historia do presente da xustiza de menores en Galicia, Servizo de Publicacións da UDC, 2008; "Coeducación en el aula universitaria. De la teoría como práctica o de cómo lo familiar se vuelve extraño», Contextos Educativos. Revista de Educación 21 (2017): 115133; «Educación universitaria y ciudadanía global: ¿puede la igualdad de género ser optativa?», Revista Educação em Questão 54, no. 40 (2016). Con la profesora Pilar Ballarín: «Educar a la ciudadanía: prostituirse no es una elección», en Oñati socio-legal series 9, $\mathrm{N}^{\circ}$ extraordinario (2019): 109-136; "Feminismo y educación. Recorrido de un camino común», Historia de la educación: Revista interuniversitaria 37 (2018): 37-67. Con la profesora Raquel Fernández-Iglesias, «Défendre une éducation inclusive dans un contexte néolibéral: l'apport des récits d'enseignant.e.s», Sociologies. [En ligne], Théories et recherches. Association internationale des sociologues de langue française (AISLF), (2019): 1-16. 